\title{
A review on biosynthesis of silver nanoparticles and their biocidal properties
}

\author{
Khwaja Salahuddin Siddiqi ${ }^{1}$, Azamal Husen ${ }^{2 *}$ and Rifaqat A. K. Rao ${ }^{3}$
}

\begin{abstract}
Use of silver and silver salts is as old as human civilization but the fabrication of silver nanoparticles (Ag NPs) has only recently been recognized. They have been specifically used in agriculture and medicine as antibacterial, antifungal and antioxidants. It has been demonstrated that Ag NPs arrest the growth and multiplication of many bacteria such as Bacillus cereus, Staphylococcus aureus, Citrobacter koseri, Salmonella typhii, Pseudomonas aeruginosa, Escherichia coli, Klebsiella pneumonia, Vibrio parahaemolyticus and fungus Candida albicans by binding Ag/Ag+ with the biomolecules present in the microbial cells. It has been suggested that Ag NPs produce reactive oxygen species and free radicals which cause apoptosis leading to cell death preventing their replication. Since Ag NPs are smaller than the microorganisms, they diffuse into cell and rupture the cell wall which has been shown from SEM and TEM images of the suspension containing nanoparticles and pathogens. It has also been shown that smaller nanoparticles are more toxic than the bigger ones. Ag NPs are also used in packaging to prevent damage of food products by pathogens. The toxicity of Ag NPs is dependent on the size, concentration, $\mathrm{pH}$ of the medium and exposure time to pathogens.
\end{abstract}

Keywords: Silver nanoparticles, Antimicrobial activity, Antioxidant activity, Green synthesis, Toxicity mechanism

\section{Introduction}

Nanoparticles exhibit novel properties which depend on their size, shape and morphology which enable them to interact with plants, animals and microbes [1-7]. Silver nanoparticles (Ag NPs) have shown excellent bactericidal properties against a wide range of microorganisms [811]. They are prepared from different perspectives, often to study their morphology or physical characteristics. Some authors have used chemical method [12] and mistaken it with green synthesis, although they have done it inadvertently. The Ag NPs and their application in electronics, catalysis, drugs and in controlling microorganism development in biological system have made them eco-friendly $[1,8,9,13]$. Biogenic synthesis of Ag NPs involves bacteria, fungi, yeast, actinomycetes and plant extracts [1, 10,11, 13-15]. Recently, a number of parts of plants such as flowers, leaves and fruits [1], besides enzymes, have been used for the synthesis of gold and

\footnotetext{
*Correspondence: adroot92@yahoo.co.in

2 Department of Biology, College of Natural and Computational Sciences, University of Gondar, P.O. Box \# 196, Gondar, Ethiopia

Full list of author information is available at the end of the article
}

silver nanoparticles. The size, morphology and stability of nanoparticles depend on the method of preparation, nature of solvent, concentration, strength of reducing agent and temperature $[1,6,10,11]$.

Of all the nanoparticles developed and characterized thus far, Ag NPs assume a significant position owing to their inherent characteristic of acting as an antimicrobial agent even in solid state. Although, its significance was recognized much earlier, it was not well exploited except for its use in oriental medicine and in coins. It is estimated that nearly 320 tons of Ag NPs are manufactured every year and used in nanomedical imaging, biosensing and food products $[16,17]$.

There is a continuous increase in the number of multidrug resistant bacterial and viral strains due to mutation, pollution and changing environmental conditions. To circumvent this predicament scientists are trying to develop drugs for the treatment of such microbial infections. Many metal salts and metal nanoparticles have been found to be effective in inhibiting the growth of many infectious bacteria. Silver and Ag NPs occupy a prominent place in the series of such metals which are used as antimicrobial agents from time immemorial [18, 
19]. Silver salts are used to inhibit the growth of a variety of bacteria in human system. They are used in catheters, cuts, burns and wounds to protect them against infection [20, 21]. Das et al. [22] have reported that small sized Ag NPs are excellent growth inhibitors of certain bacteria. Ag NPs synthesized from silk sericin (SS), a water-soluble protein extracted from silk worms at $\mathrm{pH}$ 11 , contain hydrophilic proteins with highly polar groups like hydroxyl, carboxyl and amino functional groups. Molecules containing the above functional groups act as reducing agents for $\mathrm{AgNO}_{3}$ to produce elemental silver. Aramwit et al. [23] have suggested that the hydroxyl groups of SS are supposed to form complex with silver ions and prevent their aggregation or precipitation [24, 25]. Ag NPs in elemental state may be segregated due to large molecules present in the solvent but may not be complexed as both of them are neutral. The antibacterial activity of SS-capped Ag NPs against gram positive and gram negative bacteria has been screened. It was found that MIC falls between 0.001 and $0.008 \mathrm{mM}$ for both types of microorganisms namely Staphylococcus aureus, Bacillus subtilis, Pseudomonas aeruginosa, Acinetobacter baumannii and Escherichia coli.

Although, several reviews have been published on the fabrication and characterization of silver nanoparticles, very limited reports are available on their green synthesis, biocidal properties and mechanism of action $[8,9,13$, $16,23]$. Thus, in this review, we have attempted to give a comprehensive detail of the biosynthesis of Ag NPs from herbal extracts, fungi and bacteria. Their potential as antimicrobial agent and the mechanism of their action has also been discussed.

\section{Synthesis and characterization of silver nanoparticles}

In general, metallic nanoparticles are produced by two methods, i.e. "bottom-up" (buildup of a material from the bottom: atom by atom, molecule by molecule or cluster by cluster) and "top-down" (slicing or successive cutting of a bulk material to get nano-sized particle) [1]. The "bottom-up" approach is usually a superior choice for the nanoparticles preparation involving a homogeneous system wherein catalysts (for instance, reducing agent and enzymes) synthesize nanostructures that are controlled by the catalyst itself. However, the "top-down" approach generally works with the material in its bulk form, and the size reduction to nanoscale is achieved by specialized ablations, for instance thermal decomposition, mechanical grinding, etching, cutting, and sputtering. The main demerit of the top-down approach is the surface structural defects. Such defects have significant impact on the physical features and surface chemistry of metallic nanoparticles. Several methodologies are available for the synthesis of Ag NPs namely, chemical methods [26-29]; physical methods [30-32] and biological methods [1, 10, 11]. Chemical method of synthesis can be subdivided into chemical reduction, electrochemical, irradiationassisted chemical and pyrolysis methods [33]. Ag NPs synthesis in solution requires metal precursor, reducing agents and stabilizing or capping agent. Commonly used reducing agents are ascorbic acid, alcohol, borohydride, sodium citrate and hydrazine compounds. Sotiriou and Pratsinis [28] have shown that the Ag NPs supported on nanostructured $\mathrm{SiO}_{2}$ were obtained by flame aerosol technology, which allows close control of silver content and size. Also, silver/silica nanoparticles with relatively narrow size distribution were obtained by flame spray pyrolysis [29]. However, physical methods do not require lethal and highly reactive chemicals and generally have a fast processing time. These methods include arc-discharge [31], physical vapor condensation [30], energy ball milling method [34] and direct current magnetron sputtering [32]. Physical methods have another advantage over chemical methods in that the Ag NPs have a narrow size distribution [32], while the main demerits are consumption of high energy [32]. Thus, biological synthesis of Ag NPs from herbal extract and/or microorganisms has appeared as an alternative approach as these routes have several advantages over the chemical and physical methods of synthesis. It is also a well-established fact that these routes are simple, cost-effective, eco-friendly and easily scaled up for high yields and or production [1-3]. Biosynthesis of metal and metal oxide nanoparticles using biological agents such as bacteria, fungi, yeast, plant and algal extracts has gained popularity in the area of nanotechnology $[1-3,5,6,10,11]$.

Plants and their parts contain carbohydrates, fats, proteins, nucleic acids, pigments and several types of secondary metabolites which act as reducing agents to produce nanoparticles from metal salts without producing any toxic by-product. The details have been provided in Table 1. Similarly, biomolecules such as enzymes, proteins and bio-surfactants present in microorganisms serve as reducing agents. For instance, in many bacterial strains, bio-surfactants are used as capping and/or stabilizing agents (Table 2).

Extracellular synthesis of Ag NPs comprises of the trapping of metal ions on the outer surface of the cells and reducing them in the presence of enzymes or biomolecules, while intracellular synthesis occurs inside the microbial cells. It has been suggested that the extracellular synthesis of nanoparticles is cheap, favors large-scale production and requires simpler downstream processing. Thus, the extracellular method for the synthesis of nanoparticles is preferable [164] in comparison to the intracellular method. Ganesh Babu and Gunasekaran [165] and Kalimuthu et al. 


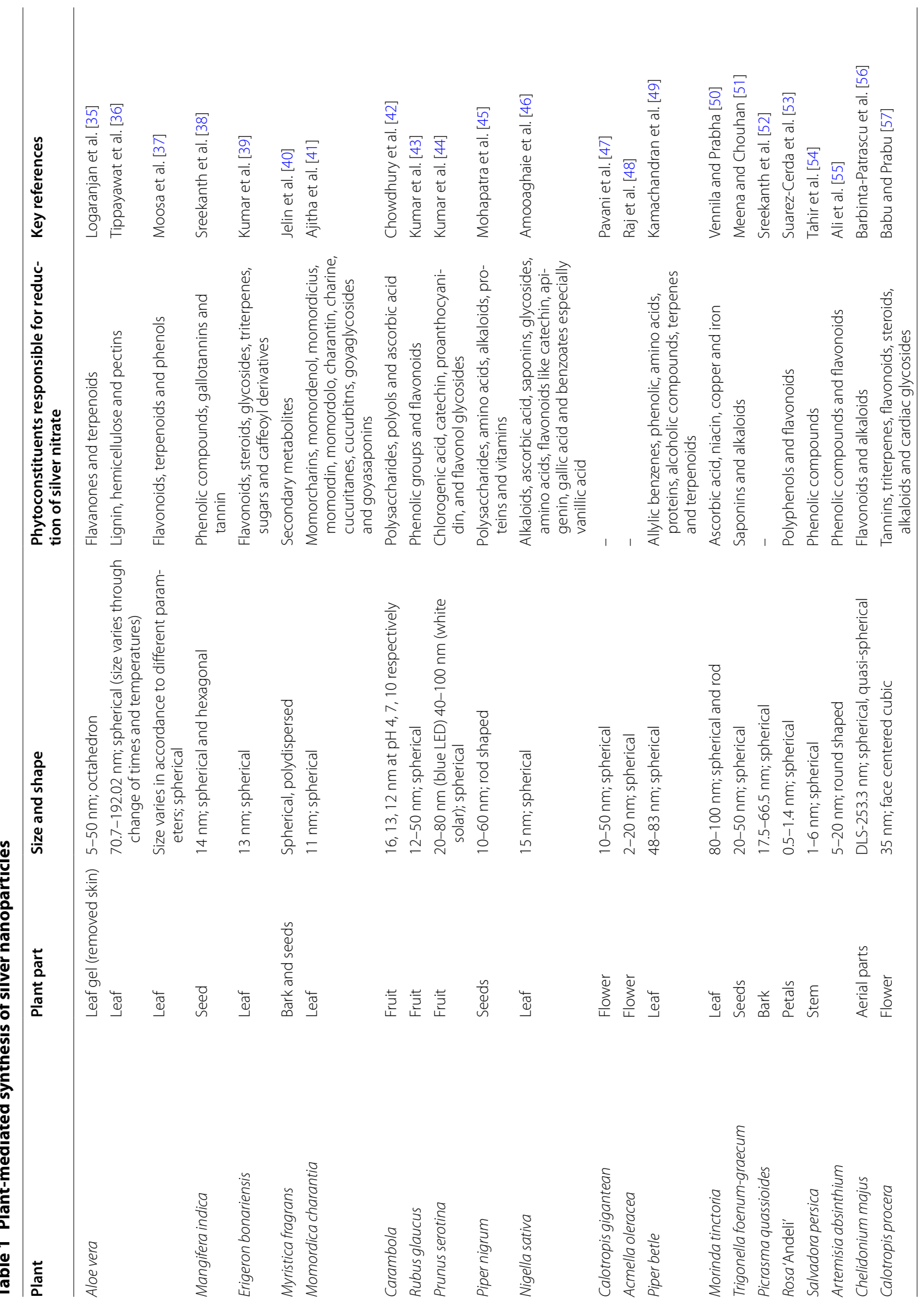




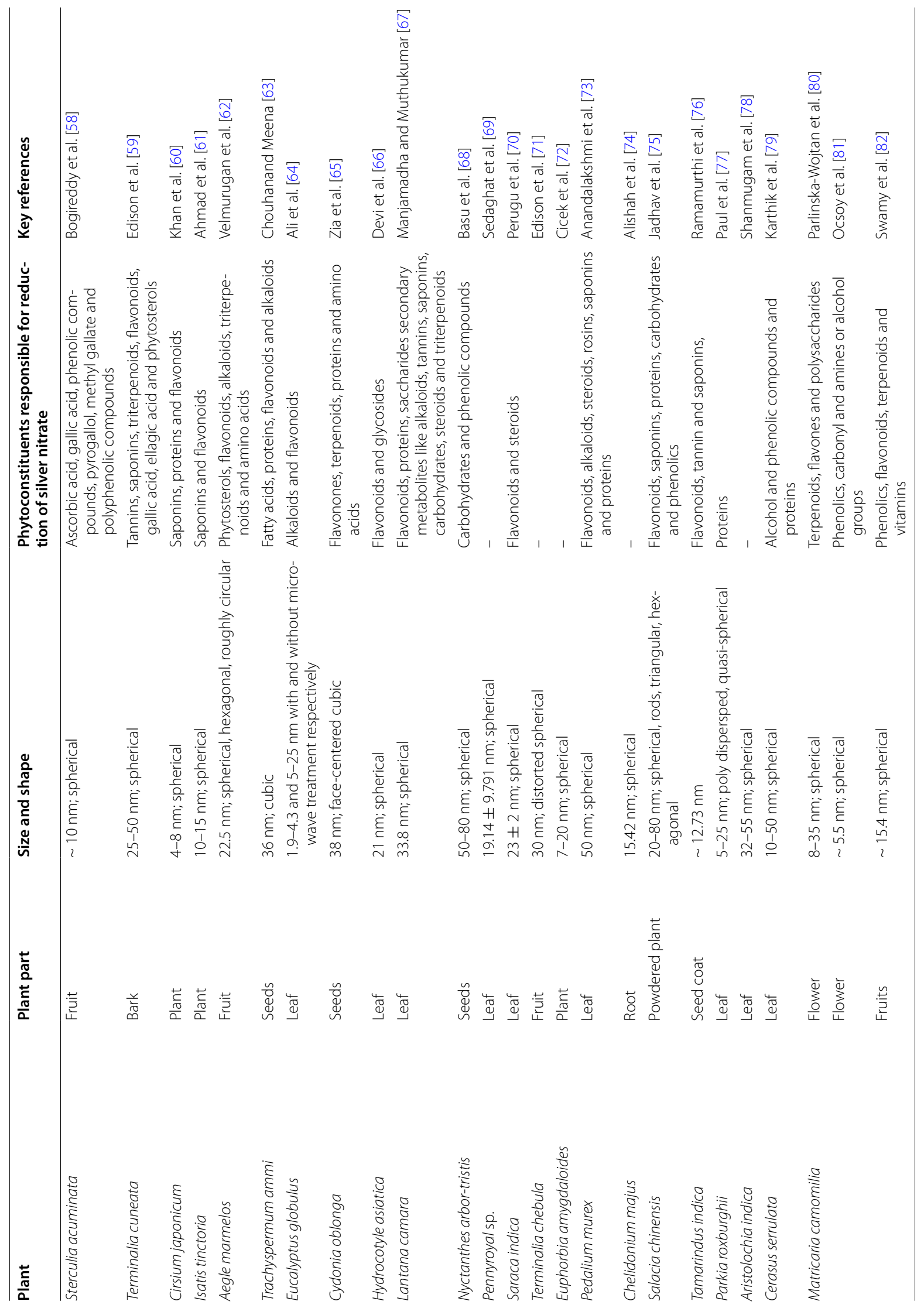




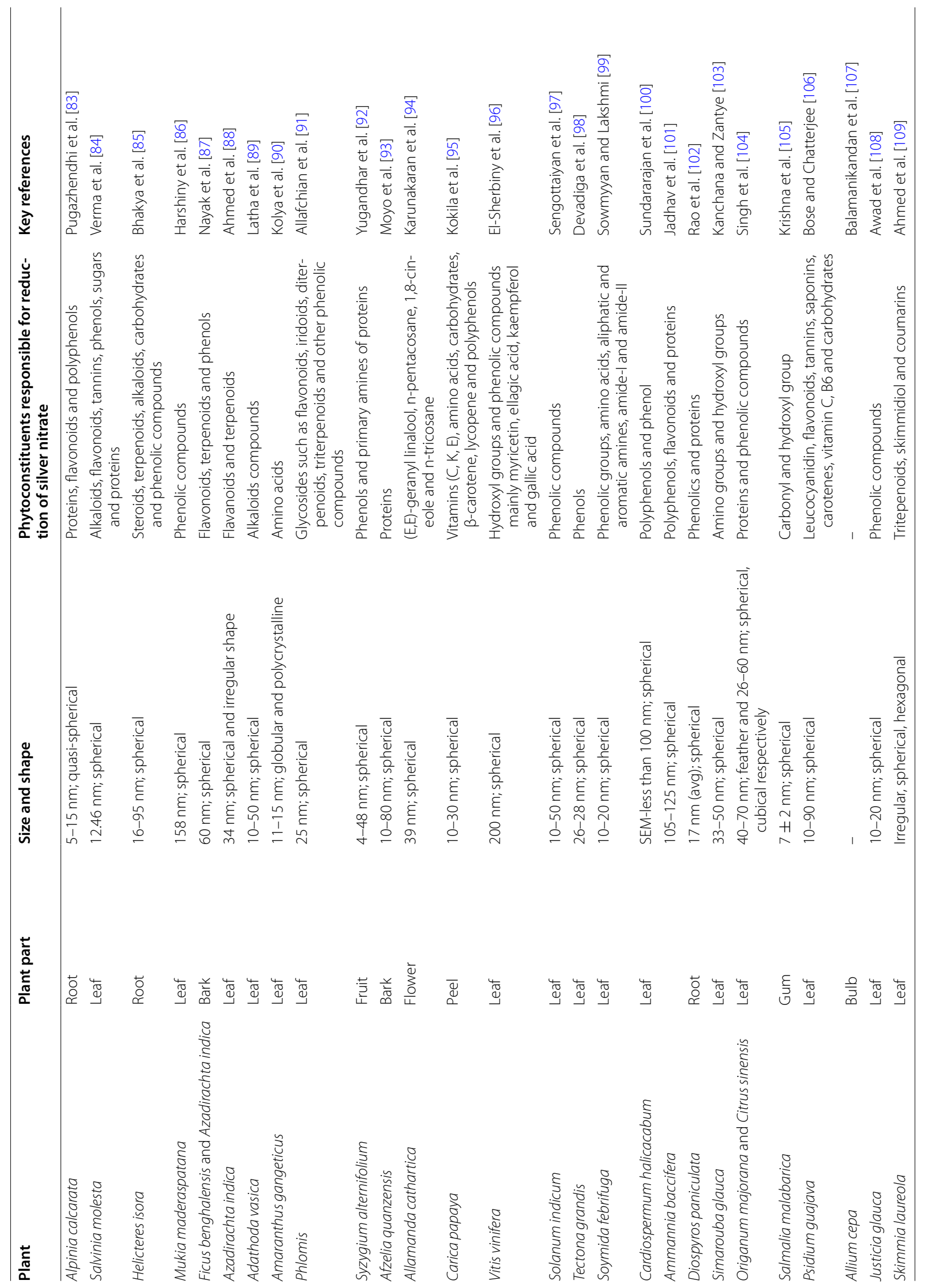




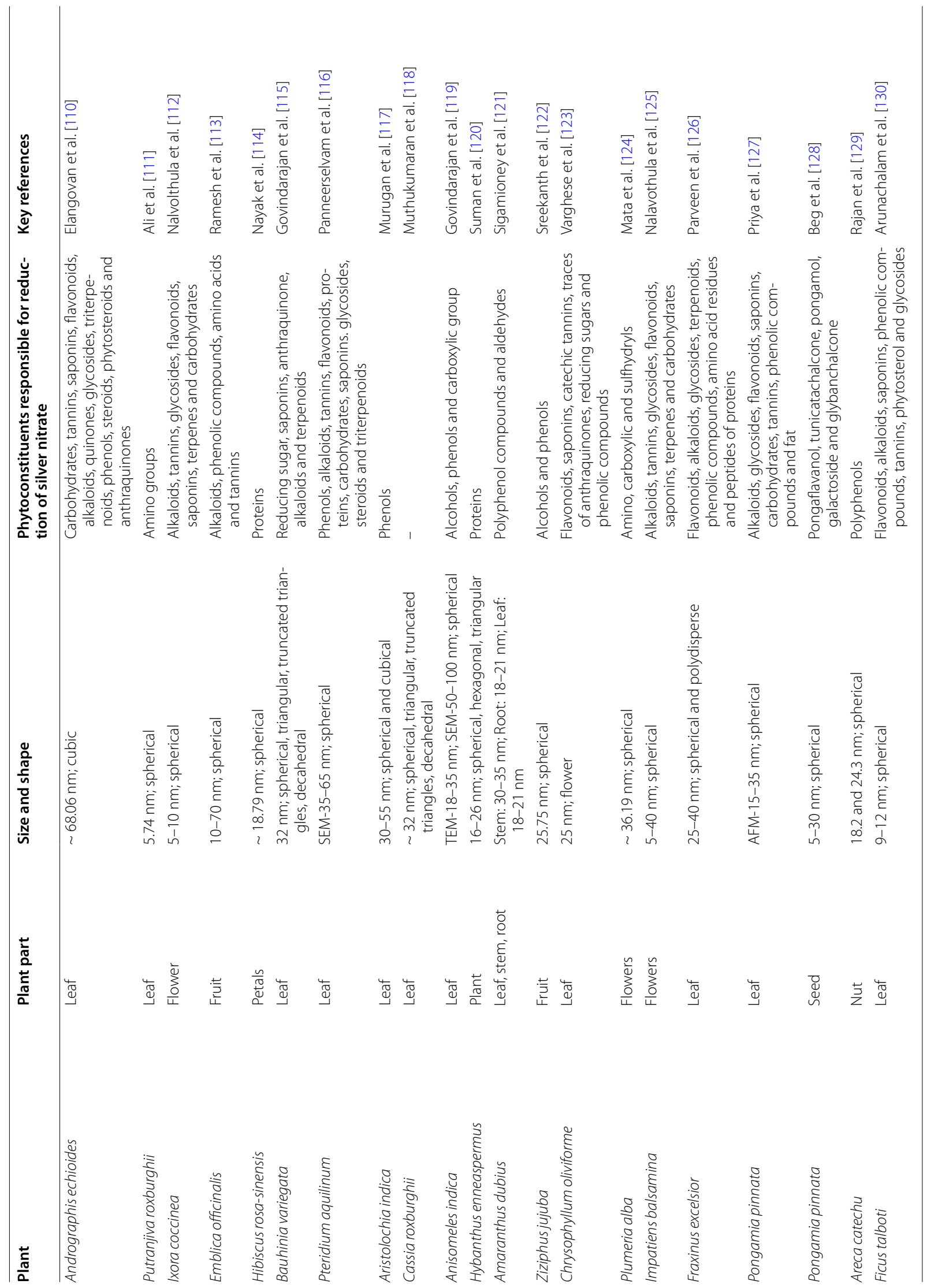




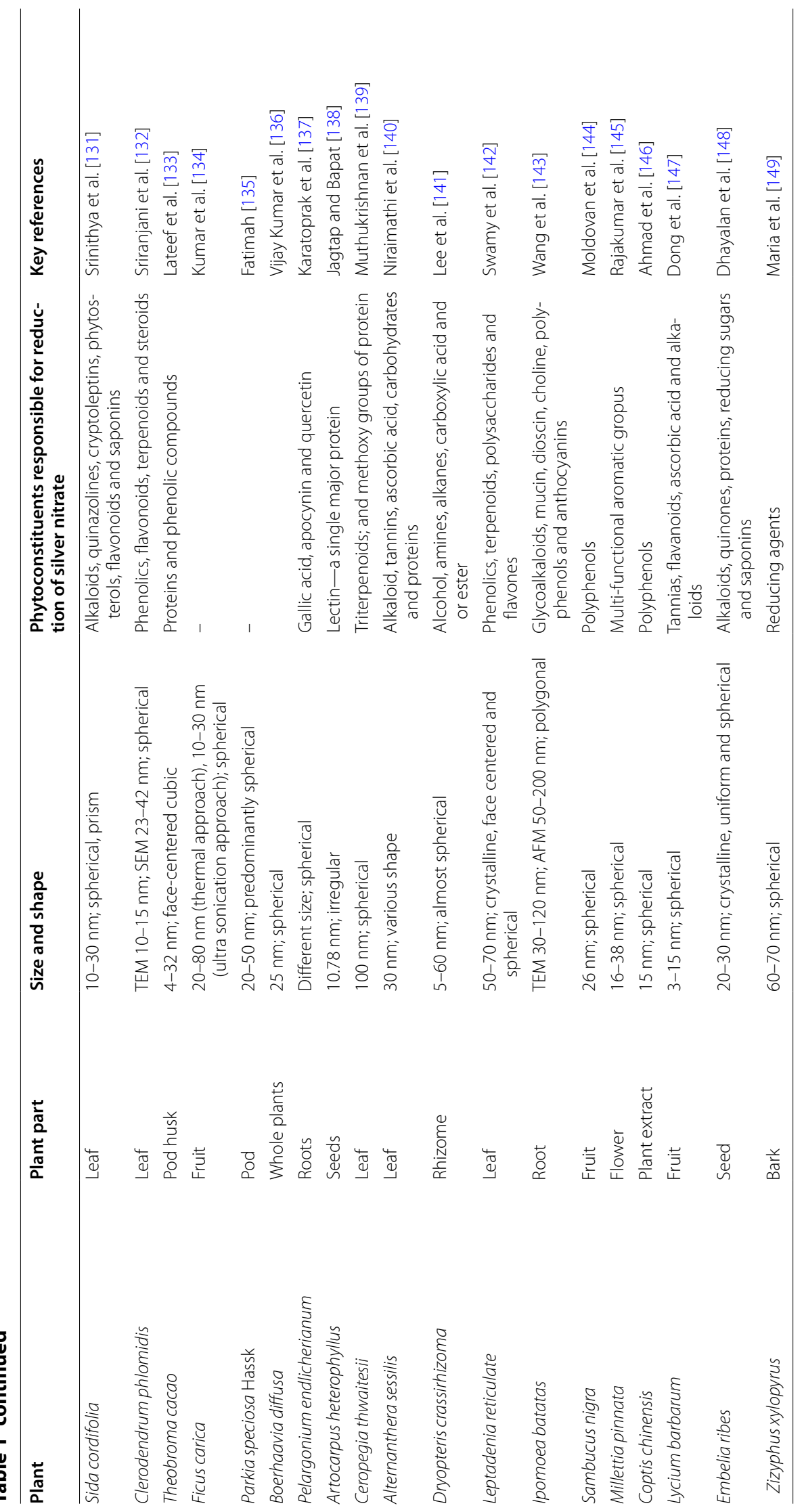


Table 2 Bio-surfactants and or stabilizing agents used during synthesis of silver nanoparticles from various bacterial stains

\begin{tabular}{llll}
\hline Bacteria & Size and shape & $\begin{array}{l}\text { Biosurfactants and or stabilizing } \\
\text { agent }\end{array}$ & Key references \\
\hline Pseudomonas aeruginosa BS-161R & $15.1 \pm 5.8 \mathrm{~nm}$; spherical & Rhamnolipids & Kumar et al. [150] \\
Brevibacterium casei MSA19 & - & Biosurfactant & Kiran et al. [151] \\
Bacillus cereus NK1 & $50-80 \mathrm{~nm}$; spherical & URAK (a fibrinolytic enzyme) & Deepak et al. [152] \\
Gluconacetobacter xylinum & $5-40 \mathrm{~nm}$ & Cellulose & Liu et al. [153] \\
Streptomyces coelicolor & $28-50 \mathrm{~nm}$; irregular & Actinorhodin pigment & Manikprabhu and Lingappa [154] \\
Bacillus subtilis MSBN 17 & $60 ;$ spherical & Bioflocculant & Sathiyanarayanan et al. [155] \\
Salmonella typhimurium & $3-11 \mathrm{~nm}$ & Flagellin & Gopinathan et al. [156] \\
Bacillus athrophaeus & $5-30 \mathrm{~nm}$; polydispersed & Spores & Hosseini-Abari et al. [157] \\
Lactobacillus rhamnosus GG ATCC & $2-15 \mathrm{~nm}$; spherical, triangular, rod- & Exopolysaccharide & Kanmani and Lim [158] \\
53103 & shaped and hexagonal & & Morsy et al. [159] \\
Nostoc commune & $15-54 \mathrm{~nm}$; spherical & Extracellular polysaccharide/matrix & Miosurfactant \\
Pseudomonas aeruginosa & $1.13 \mathrm{~nm}$; spherical & Glycolipoprotein & Farias et al. [160] \\
Ochrobactrum rhizosphaerae & $10 \mathrm{~nm}$; spherical & Glycolipid & Gahlawat et al. [161] \\
Gordonia amicalis HS-11 & $5-25 \mathrm{~nm}$; spherical & Surfactin & Sowani et al. [162] \\
Bacillus subtilis & - & & Mendrek et al. [163] \\
\hline
\end{tabular}

[166] have demonstrated that the intracellular synthesis requires additional steps for instance, ultrasound treatment or reactions with suitable detergents to release the synthesized silver nanoparticles. Further, the rate of biosynthesis of Ag NPs and their stability is a significant part in industrial production. Therefore, a proper monitoring of reaction conditions is also important (Fig. 1).

\section{From bacteria}

In recent years, the potential of biosynthesis of Ag NPs using bacteria has been realized [15, 153, 156-159]. For instance, Pseudomonas stutzeri AG259-isolated from silver mine was used to produce Ag NPs inside the cells [167]. In addition, several bacterial strains (gram negative as well as gram positive) namely $A$. calcoaceticus, $B$. amyloliquefaciens, B. flexus, B. megaterium and S. aureus have been used for both extra- and intracellular biosynthesis of Ag NPs [168-174]. These Ag NPs are spherical, disk, cuboidal, hexagonal and triangular in shape. They have been fabricated using culture supernatant, aqueous cell-free extract or cells (Table 3). Saifuddin et al. [14] have demonstrated an extracellular biosynthesis of $\mathrm{Ag}$ NPs $(\sim 5-50 \mathrm{~nm})$ using a combination of culture supernatant of $B$. subtilis and microwave irradiation in water. Shahverdi et al. [15] have reported rapid biosynthesis of Ag NPs (within $5 \mathrm{~min}$ ) using the culture supernatants of K. pneumonia, E. coli and Enterobacter cloacae. Saravanan et al. [172] have also reported an extracellular synthesis of Ag NPs using B. megaterium cultured supernatant, within minutes in presence of aqueous solutions of $\mathrm{Ag}^{+}$ions.
Rapid synthesis of Ag NPs has been achieved by the interaction of a bacterial strain S-27, belonging to Bacillus flexus group and $1 \mathrm{mM} \mathrm{AgNO}_{3}$ in aqueous medium [173]. The colourless supernatant solution turned yellow and finally brown. Its UV-vis spectrum exhibited a sharp peak at $420 \mathrm{~nm}$ due to the surface plasmon resonance (SPR) of silver nanoparticles. Anisotropic nanoparticles of 12 and $65 \mathrm{~nm}$ size were stable in the dark for 5 months at room temperature although their slow degradation cannot be prevented. They were crystalline with a face centered cubic structure. These nanoparticles were found to be effective against multidrug resistant gram positive and gram negative bacteria. The colour intensity and rate of interaction depend on the concentration of the reacting components.

Das et al. [174] have reported extracellular biosynthesis of Ag NPs from the Bacillus strain (CS11). The interaction of $1 \mathrm{mM} \mathrm{AgNO}_{3}$ with the bacteria at room temperature yielded nanoparticles within $24 \mathrm{~h}$ which showed a peak at $450 \mathrm{~nm}$ in UV-vis spectrum. Their size from TEM analysis was found to range between 42 and $92 \mathrm{~nm}$ (Table 3).

\section{From fungi}

Biosynthesis of Ag NPs from both pathogenic and nonpathogenic fungi has been investigated extensively [10, 164, 213-215] (Table 4). It has been reported that silver ions are reduced extracellularly in the presence of fungi to generate stable Ag NPs in water $[214,216]$.

Syed et al. [224] have also reported the extracellular synthesis of Ag NPs from thermophilic fungus Humicola 


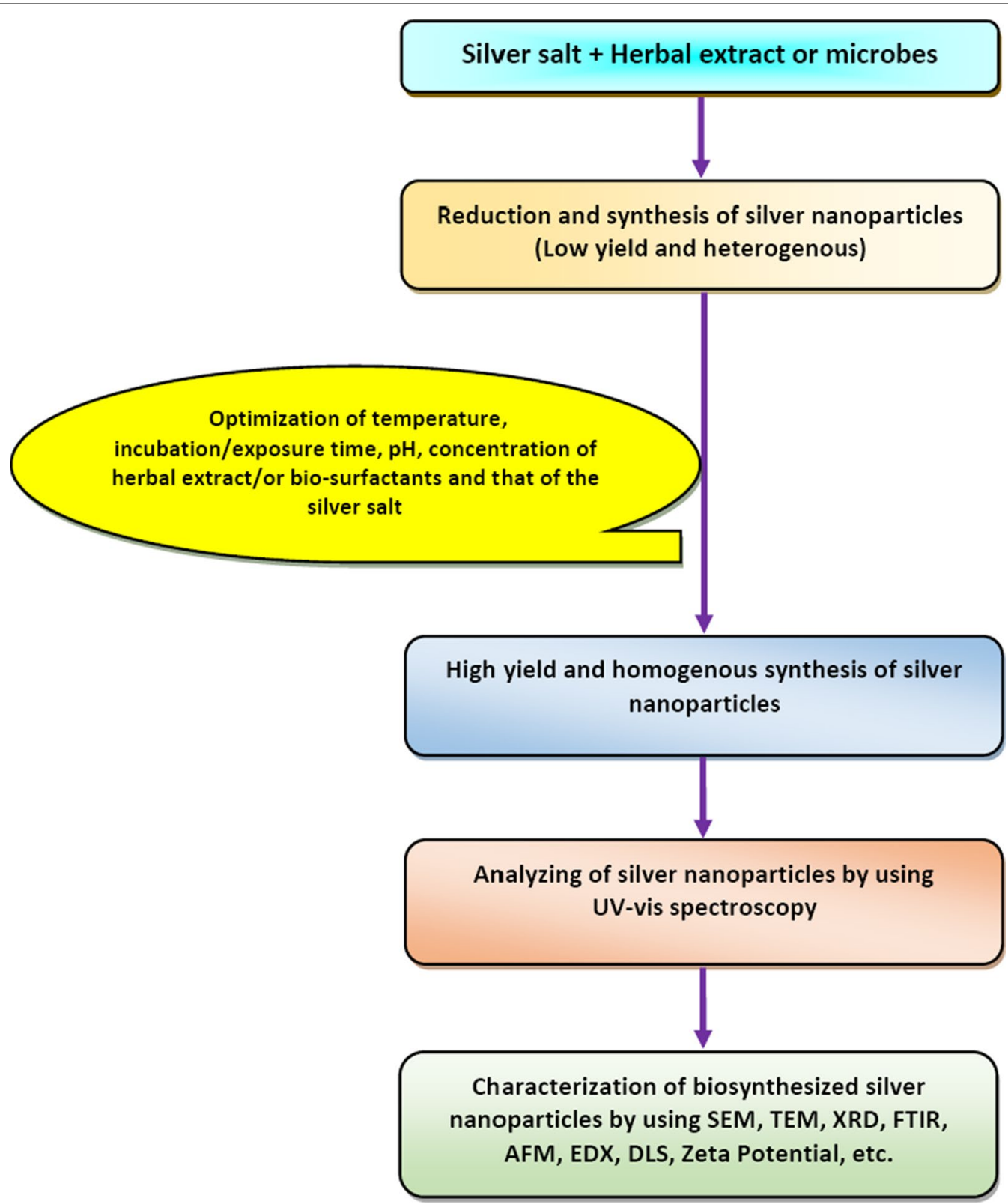

Fig. 1 Biosynthesis of silver nanoparticles and their optimization techniques

sp. All manipulations were done in aqueous medium at room temperature. Mycelia were suspended in $100 \mathrm{~mL}$ of $1 \mathrm{mM} \mathrm{AgNO}$ solution in an Erlenmeyer flask at $50{ }^{\circ} \mathrm{C}$ and the mixture was left in a shaker for $96 \mathrm{~h}$ at $\mathrm{pH}$ 9 and monitored for any change in colour. The solution showed a change in colour from yellow to brown due to the formation of Ag NPs [222]. It is a simple process for the extracellular synthesis of Ag NPs from Humicola sp. TEM micrograph showed nicely dispersed nanoparticles mainly of spherical shape ranging between 5 and $25 \mathrm{~nm}$. They are crystalline with a face centered cubic structure
[236]. IR spectrum of Ag NPs in the suspension showed peaks at 1644 and $1523 \mathrm{~cm}^{-1}$ assigned to amide $\mathrm{I}$ and amide II bands of protein corresponding to $-\mathrm{C}=\mathrm{O}$ and $\mathrm{N}-\mathrm{H}$ stretches. Owaid et al. [237] have reported the biosynthesis of Ag NPs from yellow exotic oysters mushroom, Pleurotus cornucopiae var. citrinopileatus. The dried basidiocarps were powdered, boiled in water and the supernatant was freeze dried. Different concentrations of hot water extract of this lyophilized powder were mixed with $1 \mathrm{mM} \mathrm{AgNO}$ at $25^{\circ} \mathrm{C}$ and incubated for 24 , 48 and $72 \mathrm{~h}$. Change in colour from yellow to yellowish 
Table 3 Bacteria-mediated synthesis of silver nanoparticles

\begin{tabular}{|c|c|c|c|}
\hline Bacteria & Size and shape & Location & Key references \\
\hline Acinetobacter calcoaceticus & 8-12 nm; spherical & Extracellular & Singh et al. [175] \\
\hline A. haemolyticus MMC8 & $4-40 \mathrm{~nm}$ & Extracellular & Gaidhani et al. [176] \\
\hline Aeromonas sp. SH10 & $6.4 \mathrm{~nm}$ & Extracellular and intracellular & $\begin{array}{l}\text { Mouxing et al. [177] } \\
\text { Wang et al. [178] }\end{array}$ \\
\hline Bordetella sp. & $63-90 \mathrm{~nm}$ & Extracellular & Thomas et al. [179] \\
\hline Enterobacter aerogenes & 25-35 nm; spherical & Extracellular & Karthik and Radha [180] \\
\hline Escherichia coli & 42.2-89.6 nm; spherical & Extracellular & Gurunathan et al. [181] \\
\hline Geobacter sulfurreducens & & Extracellular & Law et al. [182] \\
\hline Gluconobacter roseus & $10 \mathrm{~nm}$ & Extracellular & Krishnaraj and Berchmans [183] \\
\hline Idiomarina sp. & $25 \mathrm{~nm}$ & Intracellular & Seshadri et al. [184] \\
\hline \multirow[t]{2}{*}{ Klebsiella pneumoniae } & 15-37 nm; spherical & Extracellular & Duraisamy and Yang [185] \\
\hline & $5-32 \mathrm{~nm}$ & Extracellular & Shahverdi et al. [15] \\
\hline Morganella sp. & 10-40 nm; quasispherical & Extracellular & Parikh et al. [186] \\
\hline Proteus mirabilis & 10-20 nm; spherical & Extracellular and intracellular & Samadi et al. [187] \\
\hline \multirow[t]{3}{*}{ Pseudomonas aeruginosa SM1 } & $6.3 \pm 4.9$ nm; spherical, disk-shaped & Extracellular & Srivastava and Constanti [188] \\
\hline & 8-24 nm; spherical & Extracellular & Kumar and Mamidyala [189] \\
\hline & 5-25 nm; quasispherical & Intracellular & Otaqsara [190] \\
\hline Rhodobacter sphaeroides & Spherical 3-15 & Extracellular & Bai et al. [191] \\
\hline Rhodopseudomonas palustris & Spherical 5-20 & Extracellular & Chun-Jing and Hong-Juan [192] \\
\hline Shewanella oneidensis MR-1 & 2-16 nm; spherical (Ag2S) & Extracellular & Debabov et al. [193] \\
\hline Stenotrophomonas maltophilia & 93 nm; cuboidal & Extracellular & Oves et al. [194] \\
\hline Vibrio alginolyticus & 50-100 nm; Spherical & Extracellular and intracellular & Rajeshkumar et al. [195] \\
\hline Xanthomonas oryzae & $\begin{array}{l}14.86 \mathrm{~nm} \text {; spherical, triangular, } \\
\text { rod-shaped }\end{array}$ & Extracellular & Narayanan and Sakthivel [196] \\
\hline Yersinia enterocolitica & $10-80 \mathrm{~nm}$ & Extracellular & Pourali et al. [197] \\
\hline Bacillus sp. & $5-15 \mathrm{~nm}$ & Extracellular and periplasmic space & Pugazhenthiran et al. [198] \\
\hline B. cereus & 4-5 nm; spherical & Intracellular & Ganesh Babu and Gunasekaran [165] \\
\hline B. flexus & 12 and $65 \mathrm{~nm}$; spherical and triangular & Extracellular & Priyadarshini et al. [173] \\
\hline B. licheniformis Dahb1 & 18.69-63.42 nm; spherical & Cell free extract & Shanthi et al. [199] \\
\hline B. safensis LAU 13 & 5-30 nm; spherical & Extracellular & Lateef et al. [200] \\
\hline B. methylotrophicus DC3 & 10-30 nm; spherical & - & Wang et al. [201] \\
\hline B. subtilis & Triangular, hexagonal & Extracellular & Kannan et al. [202] \\
\hline B. subtilis MTCC 3053 & 20-60 nm; polydispersed(AgCl) & - & Paulkumar et al. [203] \\
\hline B. thuringiensis & $43.52-142.97 \mathrm{~nm}$ & Extracellular & Banu et al. [204] \\
\hline Brevibacterium casei & 10-50 nm; spherical & Intracellular & Kalishwaralal et al. [205] \\
\hline Corynebacterium SH09 & $10-15 \mathrm{~nm}$ & Extracellular & Zhang et al. [206] \\
\hline Enterococcus faecalis & $10-80 \mathrm{~nm}$ & Extracellular & Pourali et al. [197] \\
\hline Exiguobacterium sp. & 5-50 nm; spherical & Extracellular & Tamboli and Lee [207] \\
\hline Geobacillus stearothermophilus & 5-35 nm; spherical & Extracellular & Fayaz et al. [208] \\
\hline Lactobacillus mindensis & 2-20 nm; spherical $\left(\mathrm{Ag}_{2} \mathrm{O}\right)$ & Extracellular & Dhoondia and Chakraborty [209] \\
\hline Rhodococcus sp. & 10-15 nm; spherical & Extracellular & Otari et al. [210] \\
\hline Staphylococcus epidermidis & $10-80 \mathrm{~nm}$ & Extracellular & Pourali et al. [197] \\
\hline Thermoactinomyces sp. & 20-40 nm; spherical & Extracellular & Deepa et al. [211] \\
\hline Ureibacillus thermosphaericus & 10-100 nm; spherical & Extracellular & Juibari et al. [212] \\
\hline
\end{tabular}

brown exhibited an absorption peak at 420 and $450 \mathrm{~nm}$ in $\mathrm{UV}$-vis region which is the characteristic of spherical silver nanoparticles. The width of the absorption peak suggests the polydispersed nature of nanoparticles [221]. IR spectrum of Ag NPs exhibited absorption peaks at 3304, $2200,2066,1969,1636,1261,1094$ and $611 \mathrm{~cm}^{-1}$ for different groups. Although, authors have indicated the presence of polysaccharide and protein in the mushroom they 
Table 4 Fungus-mediated synthesis of silver nanoparticles

\begin{tabular}{|c|c|c|c|}
\hline Fungus & Size and shape & Location & Key references \\
\hline Aspergillu flavus & 8.92 nm; spherical & Cell wall & Vigneshwaran et al. [217] \\
\hline A. fumigatus & - & Extracellular & Bhainsa and D'Souza [218] \\
\hline A. terreus & 1-20 nm; spherical & Extracellular & Li et al. [219] \\
\hline Cladosporium cladosporioides & $10-100 \mathrm{~nm}$ & - & Balaji et al. [220] \\
\hline Coriolus versicolor & 25-75, 444-491 nm; spherical & Extracellular and intracellular & Sanghi and Verma [221] \\
\hline \multirow[t]{3}{*}{ Fusarium oxysporum } & - & Extracellular & Ahmad et al. [222] \\
\hline & 20-50 nm; spherical & Extracellular & Durán et al. [164] \\
\hline & $5-50 \mathrm{~nm}$ & - & Senapati et al. [223] \\
\hline Humicola sp. & 5-25 nm; spherical & Extracellular & Syed et al. [224] \\
\hline Macrophomina phaseolina & 5-40 nm; spherical & Cell-free filtrate & Chowdhury et al. [225] \\
\hline Pediococcus pentosaceus & - & Extracellular & Shahverdi et al. [15] \\
\hline Penicillium brevicompactum & $58.35 \pm 17.88 \mathrm{~nm}$ & - & Shaligram et al. [226] \\
\hline P.fellutanum & 5-25 nm; spherical & Extracellular & Kathiresan et al. [215] \\
\hline P. nalgiovense AJ12 & $25 \pm 2.8 \mathrm{~nm}$; spherical & Cell-free filtrate & Maliszewska et al. [227] \\
\hline Phaenerochaete chrysosporium & 5-200 nm; pyramidal & - & Vigneshwaran et al. [228] \\
\hline Phoma glomerata & 60-80 nm; spherical & - & Birla et al. [229] \\
\hline Pleurotus ostreatus & $<40$ nm; spherical & - & Al-Bahrani et al. [230] \\
\hline P. sajor-caju & $30.5 \pm 4.0 \mathrm{~nm}$; spherical & Extracellular & Vigneshwaran et al. [231] \\
\hline Trichoderma asperellum & 13-18 nm; nanocrystalline & Extracellular & Mukherjee et al. [232] \\
\hline T.reesei & $5-50 \mathrm{~nm}$ & Extracellular & Vahabi et al. [233] \\
\hline T. viride & 5-40 nm; spherical & Extracellular & Fayaz et al. [234] \\
\hline T. viride & $\begin{array}{l}\text { 2-5 nm; spherical } \\
40-65 \mathrm{~nm} \text {; rectangular } \\
\text { 50-100 nm; penta/hexagonal (Obtained at varying } \mathrm{pH} \text {, } \\
\text { reaction time and temperature of the reaction mixture) }\end{array}$ & Cell free extract & Kumari et al. [235] \\
\hline
\end{tabular}

have ignored their stretching frequencies in the IR spectrum. However, the peak at 3304 has been assigned to $v$ $(\mathrm{OH})$ of carboxylic acid and those at 2200 and $1969 \mathrm{~cm}^{-1}$ have been attributed to unsaturated aldehydes. The other peaks below $1500 \mathrm{~cm}^{-1}$ are due to unsaturated alkaloids. The field emission scanning electron and high-resolution transmission electron micrograph suggested that the $\mathrm{Ag}$ NPs are spherical with average size ranging between 20 and $30 \mathrm{~nm}$.

Very recently, Al-Bahrani et al. [230] reported biogenic synthesis of Ag NPs from tree oyster mushroom Pleurotus ostreatus. Dried aqueous extract of mushroom $(1-6 \mathrm{mg} / \mathrm{mL})$ and $1 \mathrm{mM} \mathrm{AgNO}{ }_{3}$ were mixed and incubated in the dark for 6-40 h. The colour change from pale yellow to dark brownish yellow indicated the formation of silver nanoparticles. The UV-vis spectrum showed a sharp and broad absorption band at $420 \mathrm{~nm}$. They are polydispersed nanoparticles of $10-40 \mathrm{~nm}$ with an average size of $28 \mathrm{~nm}$. Several fungi namely, Aspergillus flavus, A. fumigates, Fusarium oxysporum, Fusarium acuminatum, F. culmorum, F. solani, Metarhizium anisopliae, Phoma glomerate, Phytophthora infestans, Trichoderma viride, Verticillium sp. have been used for both extra- and intracellular biosynthesis of Ag NPs [10, 164, 216-219,
222]. These nanoparticles are of various sizes and shapes (Table 4).

\section{From plants}

Plant related parts such as leaves, stems, roots, shoots, flowers, barks, seeds and their metabolites have been successfully used for the efficient biosynthesis [1, 238] of nanoparticles (Fig. 1). Very recently, Beg et al. [128] have reported green synthesis of Ag NPs from seed extract of Pongamia pinnata. The formation of nanoparticles was confirmed by an absorption max at $439 \mathrm{~nm}$. The well dispersed nanoparticles with an average size of $16.4 \mathrm{~nm}$ had zeta potential equal to $-23.7 \mathrm{mV}$ which supports dispersion and stability. Interaction of Ag NPs with human serum albumin was investigated and showed negligible change in $\alpha$ helics. In a very recent publication Karatoprak et al. [137] have reported green synthesis of Ag NPs from the medicinal plant extract Pelargonium endlicherianum. The plant containing gallic acid, apocyanin and quercetin act as reducing agents to produce silver nanoparticles. Phytomediated synthesis of spherical Ag NPs from Sambucus nigra fruit extract has been reported by Moldovan et al. [144]. XRD analysis showed them to be crystalline. The in vivo antioxidant activity 
was investigated against Wistar rats which showed promising activity. It suggests that functionalization of $\mathrm{Ag}$ NPs with natural phytochemicals may protect the cell proteins from ROS production. Ag NPs have also been synthesized from aqueous leaf extract of Artocapus altilis. They were moderately antimicrobial and antioxidant. Thalictrum foliolosum root extract mediated Ag NPs synthesis has been confirmed on the basis of the appearance of a sharp peak at $420 \mathrm{~nm}$ in UV-vis region of the spectrum [239]. The monodispersed spherical nanoparticle of $15-30 \mathrm{~nm}$ had face centered cubic geometry. Shape and size dependent controlled synthesis of Ag NPs from Aloe vera plant extract and their antimicrobial efficiency has been reported by Logaranjan et al. [35]. The UV-vis peak at $420 \mathrm{~nm}$ confirmed the formation of silver nanoparticles. After microwave irradiation of the sample, $\mathrm{Ag}$ NPs of 5-50 nm with octahedral geometry was obtained. Nearly two to fourfold antibacterial activity of Ag NPs was observed compared to commonly available antibiotic drugs. Biosynthesis of Ag NPs from the aqueous extract of Piper longum fruit extract has been also achieved [240]. The nanoparticles were spherical in shape with an average particle size of $46 \mathrm{~nm}$ determined by SEM and dynamic light scattering (DLS) analyser. The polyphenols present in the extract are believed to act as a stabilizer of silver nanoparticles. The fruit extract and the stabilized nanoparticles showed antioxidant properties in vitro. The nanoparticles were found to be more potent against pathogenic bacteria than the flower extract of $P$. longum. Ag NPs have been fabricated from leaf extract of Ceropegia thwaitesii and formation was confirmed from absorption of SPR at $430 \mathrm{~nm}$. The nanoparticles of nearly $100 \mathrm{~nm}$ diameter were crystalline in nature [139]. Plant extract of Ocimum tenuiflorum, Solanum tricobatum, Syzygium cumini, Centella asiatica and Citrus sinensis have been used to synthesize Ag NPs of different sizes in colloidal form [249]. The size of all nanoparticles was found to be $22-65 \mathrm{~nm}$. They were all stable and well dispersed in solution. Niraimathi and co-workers [140] have reported biosynthesis of Ag NPs from aqueous extract of Alternanthera sessilis and showed that the extract contains alkaloids, tannins, ascorbic acid, carbohydrates and proteins which serve as reducing as well as capping agents. Biomolecules in the extract also acted as stabilizers for silver nanoparticles. Ag NPs from seed powder extract of Artocarpus heterophyllus have been synthesized [138]. The morphology and crystalline phase of the nanoparticles were determined by SEM, TEM and SAED, EDAX and IR spectroscopy. They were found to be irregular in shape. The extract was found to contain amino acids, amides etc. which acted as reducing agents for $\mathrm{AgNO}_{3}$ to produce silver nanoparticles. The quantity of phenols, anthocyanins and benzoic acid were determined in the berry juices and were responsible for the transformation of silver ions to Ag NPs [241]. UV-vis spectra displayed an absorbance peak at $486 \mathrm{~nm}$ for lingonberry and $520 \mathrm{~nm}$ for cranberry containing silver nanoparticles. Since the two absorption peaks are different they cannot be assigned only to Ag NPs but also partly to different quantities of the reducing chemicals present in the juices. However, the spectra indicated the presence of polydispersed silver nanoparticles. Puiso et al. [241] have proposed that due to irradiation of water by UV rays, strong oxidants and reductants as photolysis products are formed. They reduce silver ions to Ag NPs or silver oxide. The photolysis products may produce oxidant and reductant but it depends upon the quantum of radiation and exposure time which may not be enough to produce a sufficient quantity of redox chemicals to reduce $\mathrm{Ag}^{+}$to Ag NPs or $\mathrm{Ag}_{2} \mathrm{O}$. This hypothesis is conceptually incorrect because $\mathrm{Ag}_{2} \mathrm{O}$ cannot be formed as it requires a very strong oxidizing agent. On the other hand, $\mathrm{AgNO}_{3}$ itself is slowly reduced in water, but in the presence of reducing agents the reaction proceeds at a rapid rate. The SPR is dependent on the size, shape and agglomeration of $\mathrm{Ag}$ NPs which is reflected from the UV-vis spectra [242]. Mock et al. [243] have found different scattered colors in hyperspectral microscopic images which are mainly due to the different shape and size of silver nanoparticle in the colloidal solution. The blue, green, yellow and red colors have been attributed to spherical, pentagonal, round-triangle and triangle shapes, respectively.

Zaheer and Rafiuddin [12] have reported the synthesis of Ag NPs using oxalic acid as reducing agent and mistook it as green synthesis. Formation of nanoparticles was confirmed by a change in color of the solution which showed an absorption peak at $425 \mathrm{~nm}$ (Fig. 2a) in the UV-visible region. It was also noted that a scattered silver film was formed on the wall of the container that shines and reflects light (Fig. 2b) which is the characteristic of monodispersed spherical Ag NPs [244, 245]. Since the size of nanoparticles varies between 7 and $19 \mathrm{~nm}$ the silver film is not uniform. It is different from regular silver mirror due to irregular shape and size of nanoparticles (Fig. 2c). Actually, very small size nanoparticles can be obtained when $\mathrm{AgNO}_{3}$ is exposed to a reducing agent for a longer duration of time [246]. The kinetics and mechanism proposed for the formation of Ag NPs by oxalic acid is not convincing [12] because oxalic acid in no case can produce $\mathrm{CO}_{2}$ unless it reacts with any carbonate salt or heated at a very high temperature. The authors [12] have proposed following reactions to prove that the colour of Ag NPs in solution is due to $\mathrm{Ag}_{4}^{2+}$ formation that absorbs at $425 \mathrm{~nm}$ (Scheme 1). The formation of $\mathrm{Ag}_{4}^{2+}$ is highly improbable even if the above reaction is kinetically very fast. Also, the stabilization of $\mathrm{Ag}_{4}^{2+}$ is questionable 

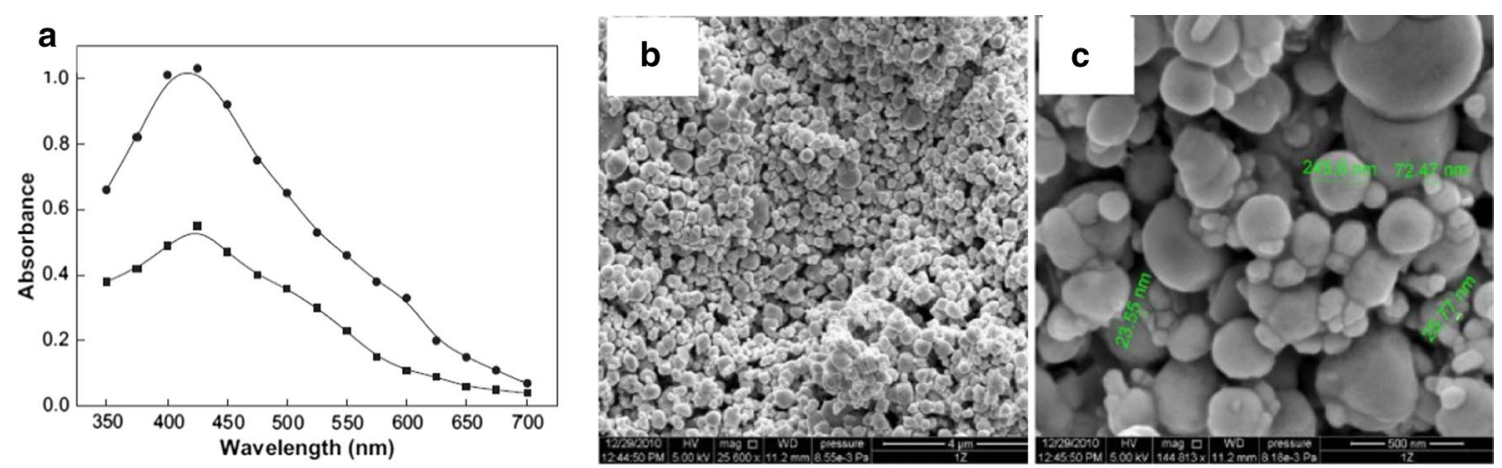

Fig. 2 a UV-visible spectra of yellow color silver solution. $\mathbf{b}$ and $\mathbf{c}$ SEM images of the self-assembled silver nanoparticle mirror like illumination on the walls of the glass. Reaction conditions: $\left[\mathrm{Ag}^{+}\right]=20.0 \times 10^{-4} \mathrm{~mol} \mathrm{dm}^{-3}$; [oxalic acid] $=4.0 \times 10^{-4} \mathrm{~mol} \mathrm{dm}^{-3} ;[\mathrm{CTAB}]=10.0 \times 10^{-4} \mathrm{~mol} \mathrm{dm}^{-3}$; temperature $=30^{\circ} \mathrm{C}[12]$

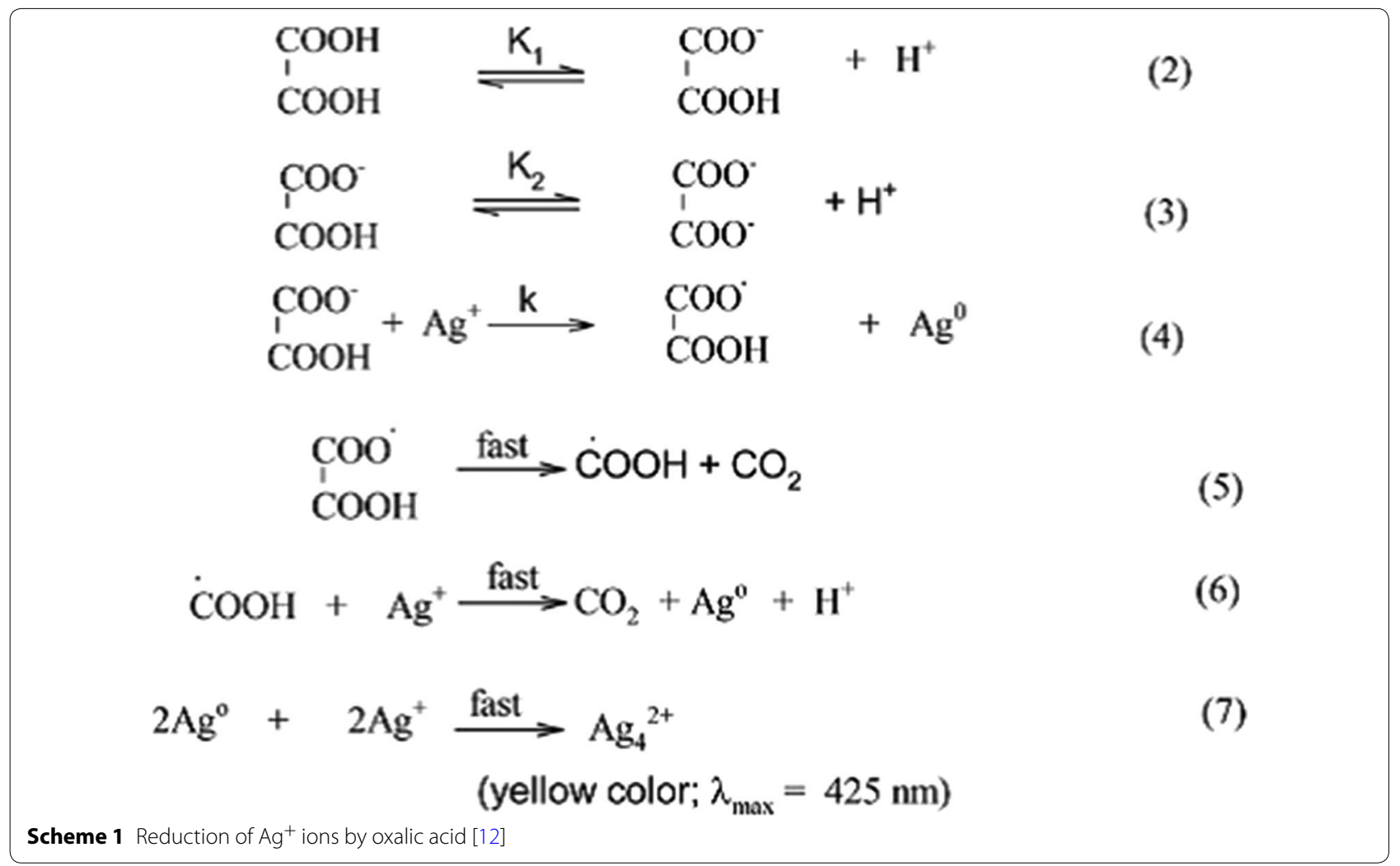

(Scheme 1). This hypothesis of $\mathrm{Ag}_{4}^{2+}$ formation is beyond imagination and does not carry any experimental evidence in its support. Absorbance of Ag NPs in solution varies between 400 and $445 \mathrm{~nm}$ depending on the nature of reducing agent used for their fabrication. The SPR band in UV-vis spectrum is due to electron oscillation around the surface of nanoparticles. The reduction process is instantaneous and no further spectral change occurs after $60 \mathrm{~min}$. Indicating the completion of redox process. Ag NPs are circular, triangular, hexagonal and polydispersed at $70{ }^{\circ} \mathrm{C}$. The EDAX and XRD spectra support each other.

Synthesis of Ag NPs from aqueous extract of Cleistanthus collinus and their characterization by UV-vis, FTIR, SEM, TEM and XRD has been reported by Kanipandian et al. [247]. The crystalline Ag NPs of 20-40 nm showed significant free radical scavenging capacity. Tippayawat et al. [27] have reported a green and facile synthesis of Ag 
NPs from Aloe vera plant extract. They were characterized by UV-vis, SEM, TEM and XRD. Fabrication of Ag NPs was confirmed on the basis of the appearance of a sharp peak at $420 \mathrm{~nm}$ in UV-vis region of the spectrum. In addition, they have reported that the reaction time and temperature markedly influence the fabrication of silver nanostructures. Ag NPs were spherical in shape and particle size ranged from $70.70 \pm 22$ to $192.02 \pm 53 \mathrm{~nm}$. Their size changes with time and temperature of the reaction mixture used during fabrication (Fig. 3).

Green synthesis of Ag NPs from Boerhaavia diffusa plant extract has been reported by Vijay Kumar et al.
[136] where the extract acted as both the reducing as well as capping agent. The colloidal solution of Ag NPs showed an absorption maximum at $418 \mathrm{~nm}$ in the UVvis spectrum. The XRD and TEM analyses revealed a face centered cubic structure with an average particle size of $25 \mathrm{~nm}$. Ag NPs of 5-60 nm have been synthesized from Dryopteris crassirhizoma rhizome extract in presence of sunlight/LED in $30 \mathrm{~min}$ [235]. XRD studies showed face centered cubic structure of silver nanoparticles.

Green synthesis of Ag NPs using $1 \mathrm{mM}$ aqueous $\mathrm{AgNO}_{3}$ and the leaf extract of Musa balbisiana (banana), Azadirachta indica (neem) and Ocimum tenuiflorum

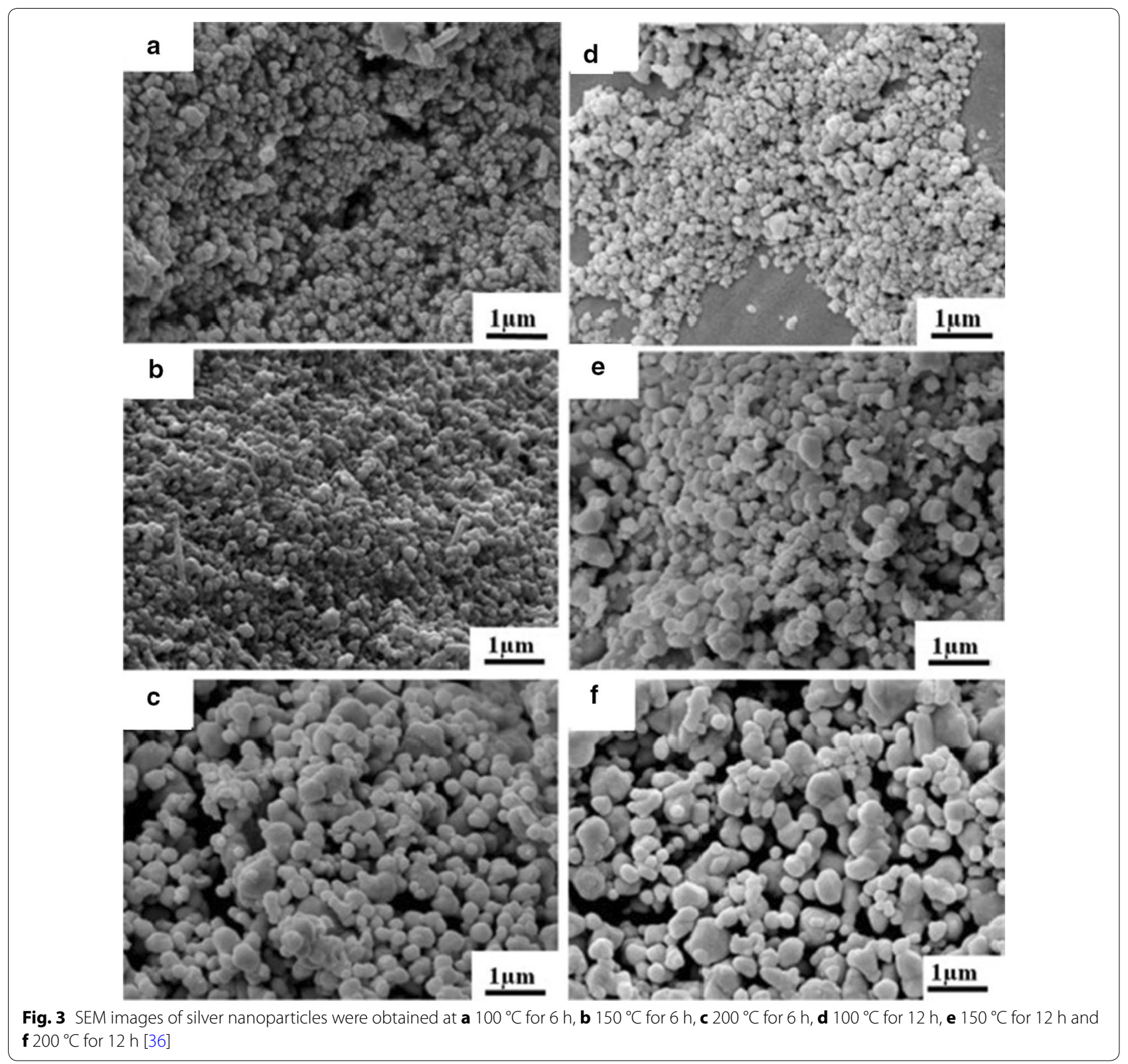


(black tulsi) has been done [248]. They were characterized by UV-vis, SEM, TEM, DLS, EDS and FTIR spectroscopy. They were found to accelerate the germination rate of Vigna radiata (Moong Bean) and Cicer arietinum (Chickpea). It is therefore, believed that Ag NPs are not toxic to such crops at germination level. Stable and capped Ag NPs from aqueous fruit extract of Syzygium alternifolium of 5-68 $\mathrm{nm}$ have been synthesized [92]. Nearly $12.7 \%$ of silver was detected from EDAX. The polydispersed spherical nanoparticles were capped and stabilized by the phenols and proteins present in the fruit extract. Biosynthesis of Ag NPs from methanolic leaf extract of Leptadenia reticulate has been done [142]. They were crystalline, face centred and spherical particles of $50-70 \mathrm{~nm}$. They exhibited antibacterial activity and radical scavenging activity. Purple sweet potato (Ipomoea batatas L.) root extract has been exploited to synthesize Ag NPs [143]. Organic components in the extract acted both as reducing and capping agents. Ag NPs have shown remarkable antibacterial activity against four clinical and four aquatic pathogens. Sweet potato root extract is known to contain glycoalkaloids, mucin, dioscin, choline, polyphenols and anthocyanins which function as antioxidant, free radical scavenger, antibacterial agent and reducing agents. In presence of Ag NPs these functions are further enhanced.

\section{Cytotoxicity of silver nanoparticles}

Cytotoxicity of nanomaterials depends on their size, shape, coating/capping agent and the type of pathogens against which their toxicity is investigated. Nanoparticles synthesized from green method are generally more toxic than those obtained from the non-green method. Some pathogens are more prone to nanomaterials, especially Ag NPs than others due to the presence of both the Ag ions released and Ag NPs. They slowly envelop the microbes and enter into the cell inhibiting their vital functions. It is clear that the fabrication and application of nanoparticles has resulted in public awareness of their toxicity and impact on the environment [249, 250]. Nanoparticles are relatively more toxic than bulk materials. They are toxic at cellular, subcellular and biomolecular levels [251]. Oxidative stress and severe lipid peroxidation have been noticed in fish brain tissue on exposure to nanomaterials [252]. The cytotoxicity by Ag NPs is believed to be produced through reactive oxygen species (ROS) as a consequence of which a reduction in glutathione level and an increase in ROS level occur. From in vitro studies on animal tissue and cultured cells, Kim and Ryu [253] have observed an increase in oxidative stress, apoptosis and genotoxicity when exposed to silver nanoparticles. Since such studies have been made with varying sizes of Ag NPs and coatings under different conditions a direct correlation cannot be made. Hackenberg and coworkers [254] reported reduced viability at a dose of $10 \mu \mathrm{g} / \mathrm{mL}$ of Ag NPs of over $50 \mathrm{~nm}$ size in human mesenchymal cells whereas some people reported no toxicity [255] even at a higher dose $(100 \mu \mathrm{g} / \mathrm{mL})$. Besides, stability and aging of the sample are also important factors as an increase in toxicity has been reported by aged Ag NPs stored in water for 6 months which is related to the release of silver ions [256]. It seems that the toxicity is a cumulative effect of Ag NPs and silver ions. Some workers have shown that the toxicity of Ag NPs is due to released Ag ions [257] while others have attributed the toxicity to Ag NPs [258].

Vijay Kumar et al. [136] obtained Ag NPs from B. diffusa plant extract and tested them against three fish bacterial pathogens. It was found that Ag NPs were most effective against Flavobacterium branchiophilum. Ag NPs fabricated from $P$. longum fruit extract exhibited cytotoxic effect against MCF-7 breast cancer cell lines with an $\mathrm{IC}_{50}$ of $67 \mu \mathrm{g} / \mathrm{mL} / 24 \mathrm{~h}$ [240]. They also exhibited antioxidant and antimicrobial effects. Ag NPs were produced by using $P$. endlicherianum plant extract; and have shown that the inhibitory activity was increased against gram positive and gram negative bacteria when they were exposed to Ag NPs at a very low dose of 7.81 to $6.25 \mathrm{ppm}$ [137]. Latha et al. [89] have fabricated Ag NPs from leaf extract of Adathoda vasica and studied their antimicrobial activity against Vibrio parahaemolyticus in agar medium. The nanoparticles were found to be significantly active against $V$. parahaemolyticus but were nontoxic to Artemia nauplii. V. parahaemolyticus is a prevalent sea food borne enteropathogen which is closely associated with mortality in Siberian tooth carps, milk fish [259], abalone [260] and shrimps [251]. Vibrio infection in cultured fish and shrimps causes large scale mortality. Quite often, the whole population perishes. The use of antibiotic has made them resistant. Under such conditions, Ag NPs have appeared as an effective remedy which saves shrimps from perishing. Ag NPs from seed powder extract of $A$. heterophyllus have also exhibited antibacterial activity against gram positive and gram negative bacteria [138].

Ag NPs fabricated from leaf extract of C. thwaitesii have shown antibacterial efficacy against Salmonella typhi, Shigella flexneri and Klbsiella pneumoniae indicating them to be significant. Niraimathi and co-workers [140] have also fabricated Ag NPs from aqueous extract of $A$. sessilis and showed significant antibacterial and antioxidant activities. Ag NPs from Ocimum tenuiflorum, Solanum tricobatum, Syzygium cumini, Centella asiatica and Citrus sinensis have also shown antibacterial activity against $S$. aureus, $P$. aeruginosa, E. coli and K. pneumoniae. The highest activity of nanoparticles was observed 
against S. aureus and E. coli [261]. Antimicrobial activity of colloidal Ag NPs was found to be higher than the plant extract alone. Lee et al. [141] synthesized Ag NPs from Dryopteris crassirhizoma and found them to be highly effective against $B$. cereus and $P$. aeruginosa. Similarly, Ag NPs obtained from leaf extract of banana, neem and black tulsi were also active against $E$. coli and Bacillus sp. [248]. Hazarika et al. [239] have performed antimicrobial screening of Ag NPs obtained from T. foliolosum root extract against six bacteria and three fungi which showed morphological changes in the bacterial cells. Fabricated of Ag NPs from Millettia pinnata flower extract and their characterization together with anti-cholinesterase, antibacterial and cytotoxic activities have been reported by Rajakumar et al. [145]. Spherical shaped Ag NPs ranging from 16 to $38 \mathrm{~nm}$ exhibited excellent inhibitory efficacy against acetyl cholinesterase and butyl cholinesterase. They also exhibited cytotoxic effects against brine shrimp.

Ag NPs obtained from S. alternifolium have also exhibited high toxicity towards bacterial and fungal isolates [92]. Ag NPs fabricated from L. reticulate [142] were found to be toxic to HCT15 cancer cell line. Kanipandian et al. [247] have reported that Ag NPs obtained from $C$. collinus aqueous extract exhibit dose dependent effects against human lung cancer cell (A549) and normal cell (HBL-100). The $\mathrm{IC}_{50}$ for cancer cells was very low $(30 \mu \mathrm{g} /$ $\mathrm{mL}$ ) but since Ag NPs synthesized from C. collinus were toxic to normal cells they cannot be used in vivo. However, if the plant extract contains some antioxidants, the whole mixture may exhibit this property but the nanoparticles alone are incapable to do so. Ag NPs from Aloe vera plant extract have shown varying degrees of antibactericidal effects [36]. Ag NPs obtained at $100{ }^{\circ} \mathrm{C}$ for $6 \mathrm{~h}$ and $200{ }^{\circ} \mathrm{C}$ for $12 \mathrm{~h}$ (varying temperature and reaction time) exhibited change in bacterial cell membrane when contacted with the nanoparticles (Fig. 4). They were more effective for gram negative bacteria (P. aeruginosa, ATCC27803). In addition, they have also shown minimal cytotoxicity to human peripheral blood mononuclear cells.

The particle size, agglomeration and sedimentation are related to the cytotoxicity of silver nanoparticles. It has been demonstrated from Alamar Blue $(\mathrm{AB})$ and Lactate dehydrogenase test (LDH) that Ag NPs of $10 \mathrm{~nm}$ coated with citrate and PVP separately, are toxic to human lung
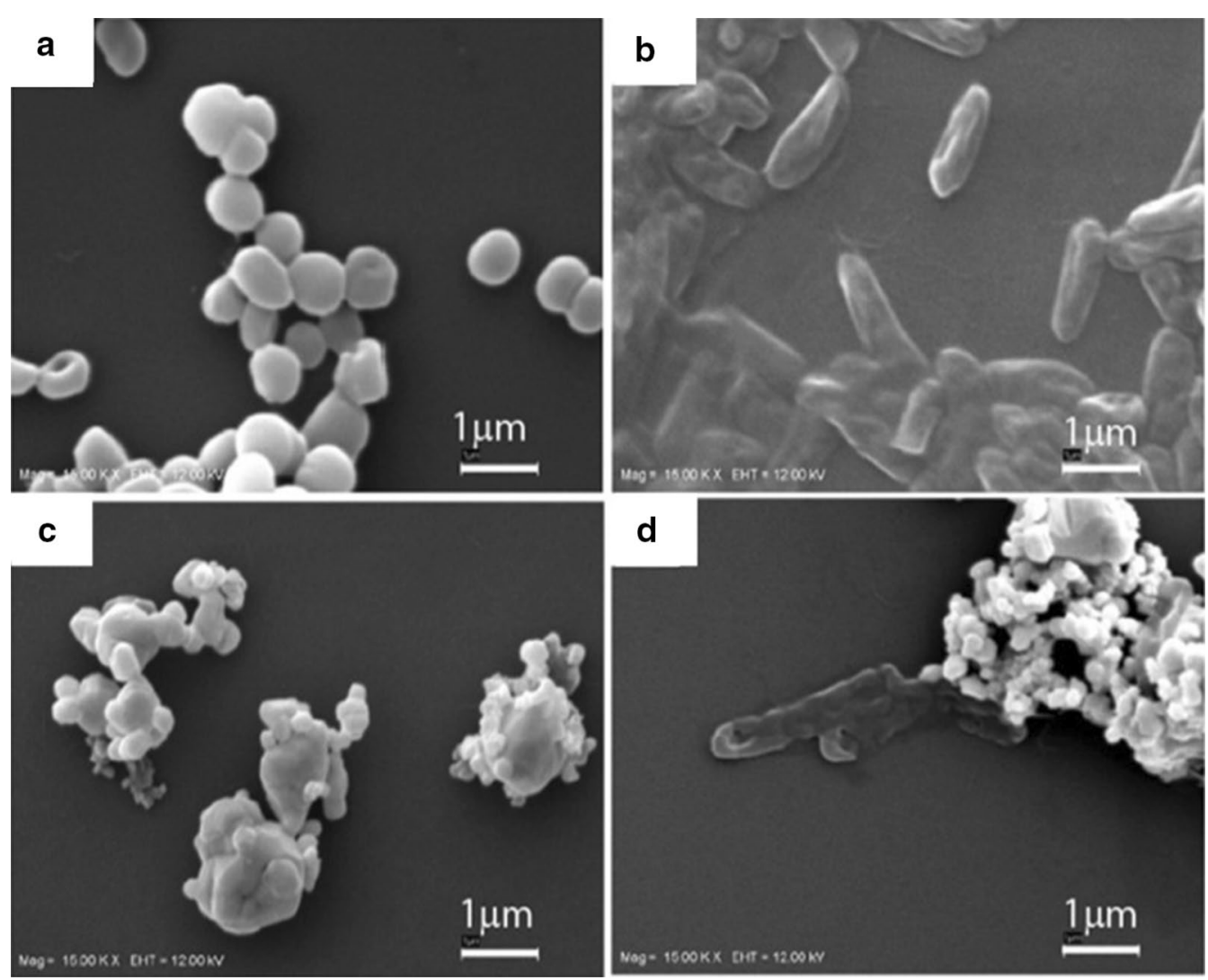

Fig. 4 SEM images of the bacterial strains. a Staphylococcus epidermidis, Gram-positive, b Pseudomonas aeruginosa, Gram-negative, c S. epidermidis treated with 100-6 h silver nanoparticles $(0.04 \mathrm{mg} / \mathrm{mL}), \mathbf{d}$ P. aeruginosa treated with 100-6 h silver nanoparticles $(0.04 \mathrm{mg} / \mathrm{mL})[36]$ 
cells [262] when exposed for $24 \mathrm{~h}$. AB test is a measure of cell proliferation and mitochondrial activity. However, the LDH measures the cytotoxicity of Ag NPs in terms of membrane damage from the cytoplasm. Both the citrate and PVP coated nanoparticles of $10 \mathrm{~nm}$ exhibited significant toxicity after $24 \mathrm{~h}$ at the highest dose of $50 \mu \mathrm{g} / \mathrm{mL}$. Ag NPs of larger dimensions did not alter cell viability [263, 264]. Cytotoxicity is related to enzyme inhibition which is correlated to the release of Ag ions because they inhibit the catalytic activity of LDH.

It has been observed that Ag NPs damaged DNA but they did not increase ROS when cells were exposed to them for $24 \mathrm{~h}$ at a dose of $20 \mu \mathrm{g} / \mathrm{mL}$ [263]. Gliga et al. [262] have suggested that silver ions from $\mathrm{AgCl}$ are released in the biological fluid and complexed. The formation of $\mathrm{AgCl}$ is possible only if the fluid is contaminated with $\mathrm{Cl}^{-}$ions, nevertheless it cannot ionize to $\mathrm{Ag}^{+}$and $\mathrm{Cl}^{-}$ions since $\mathrm{AgCl}$ is almost insoluble in aqueous medium [265]. The experiment with extracellularly released silver ions in cell medium did not exhibit toxicity, perhaps it would have reacted with $\mathrm{Cl}^{-}$ions to yield insoluble AgCl.

Cytotoxicity is related to the size of Ag NPs irrespective of the coating agent. Carlson et al. [266] have shown an increase in ROS production for $15 \mathrm{~nm}$ hydrocarbon coated Ag NPs relative to $55 \mathrm{~nm}$. It has been reported by Liu et al. [267] that $5 \mathrm{~nm} \mathrm{Ag-nanoparticles} \mathrm{were} \mathrm{more}$ toxic than 20 and $50 \mathrm{~nm}$ nanoparticles to four cell lines, namely, A549, HePG2, MCF-7 and SGC-7901. Wang et al. [268] have also reported that smaller nanoparticles $(10-20 \mathrm{~nm})$ induce greater cytotoxicity than the larger ones $(110 \mathrm{~nm})$, and citrate coated $20 \mathrm{~nm} \mathrm{Ag} \mathrm{NPs} \mathrm{pro-}$ duced acute neutrophilic inflammation in the lungs of mice compared to those with larger ones. The cell viability and DNA damage may be explained by ROS generation [269] which may be contradictory to findings by others in in vitro studies [253].

It is hypothesized that irreparable DNA damage is due to the interaction of Ag NPs with repair pathways. Since this work has been done in vitro, the DNA once damaged may not have the ability to repair. However, in living systems the cells have the ability to undergo repair and multiply but such experiments have seldom been done. It is however, unanimously agreed that both Ag NPs and silver ions are present at the subcellular level. The transformation of $\mathrm{Ag}$ to $\mathrm{Ag}^{+}$ions occurs due to their interaction with biomolecules in the cell membrane. The release of elemental silver is directly proportional to the size of nanoparticles in a non-linear fashion [270]. The size dependent toxicity is related to the intracellular release of silver ions. Although, agglomeration of nanoparticles reduces their release, the antibacterial effect was hindered under anaerobic condition, because in absence of oxygen, the oxidation process $\mathrm{Ag} \rightarrow \mathrm{Ag}^{+}$ceases to continue. Ag NPs exhibited excellent activity against $Y$. enterocolitica, P. vulgaris, E. coli, S. aureus and S. faecalis. Since the nanoparticles are smaller than the bacterial cell they may stick to their cell walls disallowing permeation of essential nutrients leading to the death of microorganisms [236]. Smaller size is related to greater surface area of nanoparticles and their agglomeration around the cell wall inhibits the cell division of microbes.

Besides their application in diverse areas, Ag NPs are extensively used as antioxidant and antimicrobial agents regardless of the process of their synthesis [271, 272]. They are more toxic to microorganisms than human beings. Antibacterial and antifungal activities of Ag NPs were tested against B. cereus, S. aureus, C. koseri, P. aeruginosa bacteria and $C$. albicans fungus respectively. It has been proposed that Ag NPs penetrate into the bacterial cell and interact with the thiol, hydroxyl and carboxyl groups of the biomolecules present in them, eventually deactivating the vital functions by releasing $\mathrm{Ag}^{+}$ions. The authors have, however, not explained how the $\mathrm{Ag}^{+}$ ions were produced. We firmly believe that silver ions must have been produced through a redox mechanism and subsequently complexed with electron donating thiol and phosphate groups inhibiting the cell replication of pathogens. It is well known that silver ions strongly bind with sulfur and oxygen containing electron donor groups in living system and arrest the functioning of vital organs that lead to the death of animal.

Ag NPs synthesized from lingonberry and cranberry juices [241] were tested for their activity against microbes commonly found in food and food products namely, $S$. aureus, S. typhi, L. monocytogenes, B. cereus, E. coli, B. subtillis and $C$. albicans. They observed that Ag NPs were more effective towards S. aureus, B. subtillis and B. cereus. Antibacterial activity was screened against $B$. cereus and S. aureus which produce toxins in food products [243]. A similar study has also been reported by Nanda and Saravanan [168] on other pathogens such as S. aureus, S. epidermidies and S. pyogens. The decrease in antimicrobial effect of Ag NPs against food borne bacteria has been ascribed to low $\mathrm{pH}$ or high $\mathrm{NaCl}$ content in food. The high concentration of $\mathrm{NaCl}$ may increase the toxicity towards bacteria because they may kill them. However, it is concluded that Ag NPs may be used in packaging to prevent infection in food products by microbes.

Zhao and Stevens [273] have studied antimicrobial effects of Ag salts on 12 species of bacteria and showed that they are highly effective against them. It has also been shown [274] that Ag NPs with amphiphilic hyperbranched macro molecules act as antimicrobial coating agents. Kim et al. [275] have thoroughly screened the antimicrobial effect of $\mathrm{Ag}$ NPs prepared from $\mathrm{AgNO}_{3}$ 
and $\mathrm{NaBH}_{4}$ as reducing agent. They examined the efficacy of a wide range of concentrations of Ag NPs starting from 0.2 to $33 \mathrm{nM}$. At a concentration of $33 \mathrm{nM}$ of Ag NPs the growth inhibition of E. coli and E. aureus was almost comparable with the positive control, although at $13.2 \mathrm{nM}$ concentration a significant effect was observed. However, the inhibitory effect of 1.6-6.6 nM of Ag NPs is nearly the same ( $\sim 55 \%$ relative to control). It was observed that silver nanoparticle is most effective against $E$. coli and has a mild inhibitory effect on S. aureus. However, gold nanoparticles of the same concentration were ineffective against these microbes, although it also belongs to the same group of elements.

$\mathrm{Ag}$ NPs synthesized from fungus Humicola sp. were investigated for their cytotoxicity on NIH3T3 mouse embryonic fibroblast cell line and MDA-MB-231 human breast carcinoma cell line [224]. In both cell lines, the cell viability declined in a dose-dependent manner. Cytotoxicity of Ag NPs was recorded at a concentration of $250 \mu \mathrm{g} / \mathrm{mL}$; the cell viability declined by $2083 \%$ in the case of NIH3T3 and $4218 \%$ for MDA-MB-231 cell line at $1000 \mu \mathrm{g} / \mathrm{mL}$ concentration. Very recently [269], it has been investigated that Ag NPs in conjugation with other metals such as $\mathrm{TiO}_{2} @ \mathrm{Ag}$ nanoparticles act against leishmaniasis. These nanoparticles along with other drugs for leishmania, like neglumine antimoniate at nontoxic concentrations increase the efficacy of both drugs. This combination of drug led to the inhibition of L. tropica amastigotes at a very high rate of $80-95 \%$. Also, it increased the metabolic activities 7-20-fold.

Owaid et al. [237] have produced Ag NPs from aqueous extract of $P$. cornucopiae var. citrinopileatus which served both as reducing and stabilizing agent. Their antimicrobial activity was investigated against four pathogenic Candida sp. namely C. albicans, C. glabrate, C. krusei and C. pseudotropicalis. Ag NPs at $60 \mu \mathrm{g} /$ well showed a significant increase in inhibition of candida sp. However, pure extract was ineffective against all microbes at $20-40 \mu \mathrm{g} / \mathrm{well}$. Mechanism of action has been ascribed to the interaction between the positive charge on silver ion and the negative charge on the cell membrane of microorganism [25, 35]. Due to electrostatic attraction between the two the silver ions penetrate into the microbial cell via diffusion leading to their death. Ag NPs synthesized using fungus Trichoderma viride were examined for their antimicrobial activity in combination with various antibiotics (ampicillin, kanamycin, erythromycin and chloramphenicol) against both gram positive and gram negative bacteria [234]. Antibacterial activities of antibiotics were increased in the presence of Ag NPs against the tested strains and $P$. aeruginosa. The original aqueous extract of $P$. ostreatus was found to be ineffective against all bacterial strains at $25-75 \mu \mathrm{g} / \mathrm{mL}$.
Allahverdiyev et al. [276] have reported that the combination of Ag NPs with antibiotics decreases the toxicity toward human cells by reducing the required dosage. Furthermore, these combinations restore the ability of the drug to kill bacteria that have acquired resistance to them [175]. Hence, a separate approach of using Ag NPs synthesized from bacterial strains alone and in combination can act as effective novel antimicrobials to sensitize resistant pathogens. Nevertheless, a study with E. coli has demonstrated that the bacteria could become resistant to Ag NPs on its regular exposure for 225 generations through genetic mutations [277]. Thus, a precaution should be taken to avoid the constant exposure of microorganisms against such types of nanoparticles. In addition, treatment with bacterial Ag NPs has shown the cell viability reduction in a dose-dependent manner in HeLa cervical cancer [278, 279], MDA-MB-231breast cancer [280], A549 adenocarcinoma lung cancer [281] and HEP2 [282] cell lines. Ag NPs produced from bacterial strains exhibited cytotoxicity to cancer cells but their impact on normal healthy cells cannot be ignored.

\section{Mechanism of antibacterial activity}

As discussed previously, several reports are available which have shown that Ag NPs are effective against pathogenic organisms namely B. subtilis, Vibrio cholerae, E. coli, P. aeruginosa, S. aureus, Syphilis typhus etc. [10, 11, 109, 145]. Ag NPs with larger surface area provide a better contact with microorganisms [283]. Thus, these particles are capable to penetrate the cell membrane or attach to the bacterial surface based on their size. In addition, they were reported to be highly toxic to the bacterial strains and their antibacterial efficiency is increased by lowering the particle size [284]. Many arguments have been given to explain the mechanism of growth inhibition of microbes by Ag NPs but most convincing is the formation of free radical which has also been supported by the appearance of a peak at 336.33 in the electron spin resonance (ESR) spectrum of Ag NPs [275]. The free radical generation is quite obvious because in a living system they can attack membrane lipids followed by their dissociation, damage and eventually inhibiting the growth of these microbes [285]. It is worth noting that the equal mass of silver Ag NPs and that of Ag ions exhibit identical growth inhibition of $E$. coli and S. aureus. In a study, the highly antibacterial activity has been ascribed to the release of silver cation from Ag NPs [173]. The Ag+ permeated into bacteria through the cell wall $[286,287]$ as a consequence of which the cell wall ruptures leading to denaturation of protein and death. Since $\mathrm{Ag}$ ions are positively charged and much smaller than neutral Ag NPs they can easily interact with electron rich biomolecules in the bacterial cell wall containing $\mathrm{S}$ or $\mathrm{P}$ and $\mathrm{N}$. Some 
researchers have reported that interaction between the positive charge on Ag NPs and negative charge on the cell membrane of the microorganisms is the key to growth inhibition of the microbes [286, 287]. On the other hand, Sondi et al. [288] have reported that antibacterial activity of Ag NPs toward gram negative bacteria depends on its concentration. The nanoparticles form pits in the cell wall of microbes, get accumulated, and permeate into the bacterial cell leading to their death. It has been reported $[289,290]$ that Ag free radical formation and antimicrobial property are inter related which has been confirmed by ESR [275]. They claim that such an antimicrobial study included both the positively charged silver ions and negatively charged silver nanoparticles.

The absorption of Ag NPs at $391 \mathrm{~nm}$ is the signature of spherical nanoparticles due to their surface plasmon resonance [291]. This absorption spectrum does not undergo any change even when the suspension of Ag NPs is diluted ten times indicating that they are not agglomerated. Besides Ag NPs and silver compounds, there are other inorganic ions which also possess antibacterial properties [241, 287, 292]. It is known that silver ions bind to the protein of the microorganisms preventing their further replication but the organisms also avoid interacting with these ions and produce cysts to become resistant.

Ag NPs may be oxidized to $\mathrm{Ag}^{+}$but cannot be reduced $[287,289]$. Silver is known to have $4 d^{10}, 5 s^{1}$ outermost electronic configuration and it cannot hold an extra electron to become $\mathrm{Ag}^{-}$anion. Silver salt of sulphathiazine is used in burn therapy to protect the skin from infection by pseudomonas species. Silver is released slowly from the salt which is sufficiently toxic to microorganisms. Since the salt is sparingly soluble the silver acts on the external cell structure. Silver salt and Ag NPs exhibit cytotoxicity against a broad range of microorganisms, although the toxicity depends on the quantum of silver ions released [275].

The monodispersed nanoparticles of uniform size are produced. Graphene oxide exhibits antibacterial activity against $E$. coli $[293,294]$ but Ag NPs functionalized graphene based material show enhanced antibacterial activity [295, 296]. Graphene oxide is nicely dispersed in polar solvents like water which allows the deposition of nanoparticle for its use in various fields. Antibacterial activity of both Ag NPs and Ag-graphene oxide composite has been tested in a wide range of concentration between 6.25 and $100 \mu \mathrm{g} / \mathrm{mL}$ against both gram positive and gram negative bacteria. It was noticed that both $\mathrm{Ag}$ NPs and Ag-graphene oxide composite were more effective against gram positive than gram negative bacterial strains. Ag-graphene oxide is a better growth inhibitor of S. Typhi, even at a very low concentration of $6.25 \mu \mathrm{g} / \mathrm{mL}$, than Ag NPs of the same concentration. However, Ag NPs and Ag-graphene oxide do not show any inhibitory effect against gram positive bacteria, S. aureus and S. epidermis below $50 \mu \mathrm{g} / \mathrm{mL}$. It was also noted that graphene oxide alone is ineffective against these bacteria even at a higher concentration of $100 \mu \mathrm{g} / \mathrm{mL}$ [293, 296].

Silver ions released from Ag NPs may penetrate into bacterial cell components such as peptidoglycan, DNA and protein preventing them from further replication [297, 298]. Release of $\mathrm{Ag}^{+}$ions means the oxidation of elemental silver which requires an oxidizing agent.

Silver nanoparticle $\rightarrow \mathrm{Ag}^{+}+\mathrm{e}^{-}$

The organic groups like carbonyl and protein in the bacterial cell wall are electron donors rather than electron acceptors and hence they cannot produce $\mathrm{Ag}^{+}$ions from $\mathrm{Ag}$ atoms, nevertheless the $\mathrm{Ag}^{+}$ions are produced which confirms the presence of an oxidizing agent [296, 299]. $\mathrm{Ag}^{+}$ions are thus bonded to the proteins of bacteria and inhibit their vital functions.

Tho et al. [300] have shown that spherical Ag NPs of 2.76-16.62 nm size fabricated from Nelumbo nucifera seed extract are highly toxic to Gram negative bacteria. The antibacterial property has been ascribed to the attachment of Ag NPs to the surface of cell membrane disallowing permeation and respiration of the cells.

The outer layer of gram negative bacteria is made up of a lipopolysaccharide layer and the inner layer is composed of a linear polysaccharide chain forming a three-dimensional network with peptides. Ag NPs get accumulated due to attraction between the negative charge on the polysaccharides and weak positive charge on the silver nanoparticles. It stops the cell replication of the microbes.

Toxicity by nanoparticles is generally triggered by the formation of free radicals, such as ROS [301, 302]. If the ROS is produced it may cause membrane disruption and disturb the permeability. The mechanism of growth inhibition follows electrostatic interaction, adsorption and penetration of nanoparticles into the bacterial cell wall. Toxicity of nanoparticles also depends on composition, surface modification, intrinsic properties and type of microorganisms [9, 303-306]. For instance, $\mathrm{TiO}_{2}$-nanoparticles can increase peroxidation of the lipid membrane disrupting the cell respiration [307]. The biogenic Ag NPs in combination with antibiotics like erythromycin, chloramphenicol, ampicilin and kanamycin enhance the toxicity against gram positive and gram negative bacteria $[308,309]$. A possible mechanism is presented in Fig. 5. Besides, Ag NPs are also toxic to nitrifying bacteria [310]. The ROS include superoxide $\left(\mathrm{O}_{2}{ }^{-}\right)$, hydroxyl ("OH), peroxy (RCOO") and hydrogen peroxide $\left(\mathrm{H}_{2} \mathrm{O}_{2}\right)$. RNS includes nitric oxide (NO") and 


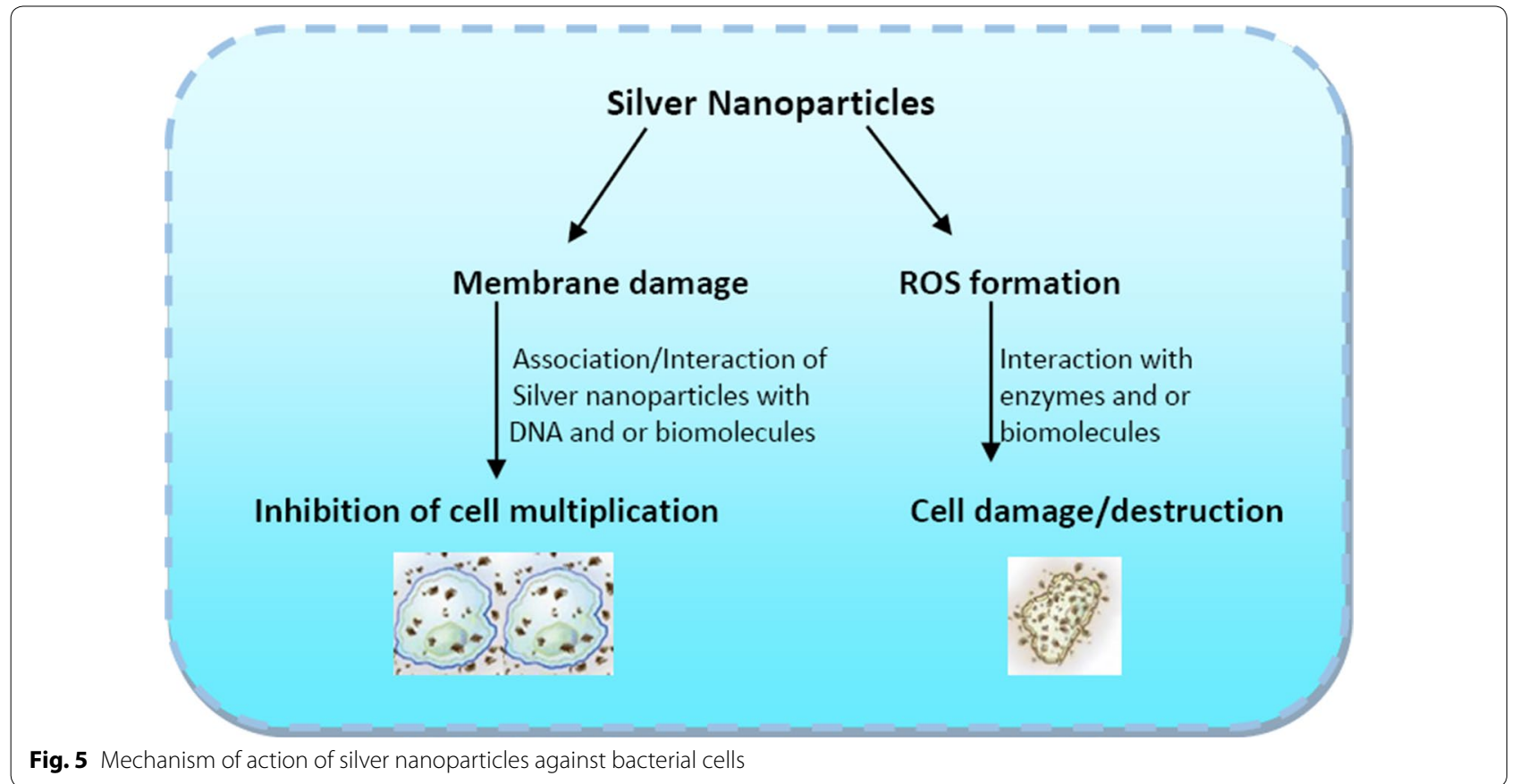

nitrogen dioxide $\left(\mathrm{NO}_{2}{ }^{-}\right)[311,312]$. The cell replication and development of microbes in ROS containing atmosphere will cease to continue. However, this process may be delayed in presence of an antioxidant such as an enzyme or a non-enzymatic component which scavenges the free radicals [313].

\section{Conclusion}

Regardless of the method of fabrication, Ag NPs are used as an antimicrobial agent, electrochemical sensors, biosensors, in medicine, health care, agriculture and biotechnology. They have great bactericidal potential against both gram positive and gram negative pathogens. Since Ag NPs coupled with antibiotics are active against many drug resistant bacteria they can be used as easily accessible medicine for the treatment of several infections. Ag NPs in the drug delivery system, quite often increase the solubility, stability and bio-distribution enhancing their efficiency. In presence of nanoparticles the absorption of medicine increases several times therefore, Ag NPs may be used as a drug delivery system.

Although, the long-term effect of nanoparticles on human health and crops is not clear. A large number of nanoparticles are being explored in many areas of industry technology, biotechnology and agriculture. It is known that various forms of silver from laundry, paints, clothes etc. and biosolids reach the sewage and sludge. It has been reported that nano sized $\mathrm{Ag}_{2} \mathrm{~S}$ are formed in the activated sludge as a consequence of the reaction between silver nanoparticles/ $\mathrm{Ag}^{+}$ions and the sulfide produced in sewage. It is not possible for Ag NPs in the elemental form to react with evolved $\mathrm{H}_{2} \mathrm{~S}$. Only $\mathrm{Ag}^{+}$ions may react with $\mathrm{H}_{2} \mathrm{~S}$ to yield $\mathrm{Ag}_{2} \mathrm{~S}$ according to the reaction given below.

$$
2 \mathrm{AgNO}_{3}+\mathrm{H}_{2} \mathrm{~S} \rightarrow \mathrm{Ag}_{2} \mathrm{~S}+2 \mathrm{HNO}_{3}
$$

$\mathrm{Ag}_{2} \mathrm{~S}$ or $\mathrm{AgNO}_{3}$ may be ionized to give free $\mathrm{Ag}^{+}$ions which inhibit the bacterial growth. Besides many advantages of Ag NPs there are some disadvantages too. They inhibit the growth of nitrifying bacteria, thereby inhibiting the biological nitrogen removal. As little as 1-20 ppm Ag NPs have been reported to be effective against microbes. It is anticipated that Ag NPs may be used as an inexpensive broad spectrum antimicrobial agent to protect plant crops and infections in human beings.

\section{Authors' contributions}

AH, KSS and RAKR gathered the research data. AH and KSS analyzed these data and wrote this review paper. All the authors read and approved the final manuscript.

\section{Author details}

${ }^{1}$ Department of Chemistry, Aligarh Muslim University, Aligarh, Uttar Pradesh 202002, India. ${ }^{2}$ Department of Biology, College of Natural and Computational Sciences, University of Gondar, P.O. Box \# 196, Gondar, Ethiopia. ${ }^{3}$ Department of Applied Chemistry, Zakir Husain College of Engineering and Technology, Aligarh Muslim University, Aligarh, Uttar Pradesh 202002, India.

\section{Acknowledgements}

Authors are thankful to publishers for permission to adopt figures in this review.

\section{Competing interests}

The authors declare that they have no competing interests. 
Availability of data and materials

Not applicable.

\section{Consent for publication}

Not applicable.

\section{Ethics approval and consent to participate}

Not applicable.

\section{Funding}

Not applicable.

\section{Publisher's Note}

Springer Nature remains neutral with regard to jurisdictional claims in published maps and institutional affiliations.

Received: 6 September 2017 Accepted: 19 January 2018

Published online: 16 February 2018

\section{References}

1. Husen A, Siddiqi KS. Phytosynthesis of nanoparticles: concept, controversy and application. Nano Res Lett. 2014;9:229.

2. Husen A, Siddiqi KS. Plants and microbes assisted selenium nanoparticles: characterization and application. J Nanobiotechnol. 2014;12:28.

3. Siddiqi KS, Husen A. Green synthesis, characterization and uses of palladium/platinum nanoparticles. Nano Res Lett. 2016;11:482

4. Husen A, Siddiqi KS. Carbon and fullerene nanomaterials in plant system. J Nanobiotechnol. 2014;12:16.

5. Siddiqi KS, Rahman A, Tajuddin Husen A. Biogenic fabrication of iron/iron oxide nanoparticles and their application. Nano Res Lett. 2016;11:498.

6. Siddiqi KS, Husen A. Recent advances in plant-mediated engineered gold nanoparticles and their application in biological system. J Trace Elements Med Biol. 2017;40:10-23.

7. Siddiqi and Husen. Engineered gold nanoparticles and plant adaptation potential. Nano Res Lett. 2016;11:400.

8. Wei L, Lu J, Xu H, Patel A, Chen ZS, Chen G. Silver nanoparticles: synthesis, properties, and therapeutic applications. Drug Discov Today. 2015;20:595-601.

9. Lara HH, Garza-Trevino EN, Ixtepan-Turrent L, Singh DK. Silver nanoparticles are broad-spectrum bactericidal and virucidal compounds. J Nanobiotechnol. 2011;9:30.

10. Siddiqi KS, Husen A. Fabrication of metal nanoparticles from fungi and metal salts: scope and application. Nano Res Lett. 2016;11:98.

11. Siddiqi KS, Husen A. Fabrication of metal and metal oxide nanoparticles by algae and their toxic effects. Nano Res Lett. 2016:11:363.

12. Zaheer Z, Rafiuddin. Silver nanoparticles to self-assembled films: Green synthesis and characterization. Colloids Surf B Biointerfaces. 2012;90:48-52.

13. Lokina S, Stephen A, Kaviyarasan V, Arulvasu C, Narayanan V. Cytotoxicity and antimicrobial activities of green synthesized silver nanoparticles. Euro J Med Chem. 2014;76:256-63.

14. Saifuddin N, Wong CW, Yasumira AAN. Rapid biosynthesis of silver nanoparticles using culture supernatant of bacteria with microwave irradiation. e-J Chem. 2009;6:61-70.

15. Shahverdi AR, Minaeian S, Shahverdi HR, Jamalifar H, Nohi AA. Rapid synthesis of silver nanoparticles using culture supernatants of Enterobacteria: a novel biological approach. Process Biochem. 2007:42:919-23.

16. Ahamed M, AISaalhi MS, Siddiqui MKJ. Silver nanoparticle applications and human health. Clin Chim Acta. 2010;411:1841-8.

17. Chen $\mathrm{X}$, Schluesener HJ. Nanosilver: a nanoproduct in medical application. Toxicol Lett. 2008;176:1-12.

18. Jones SA, Bowler PG, Walker M, Parsons D. Controlling wound bioburden with a novel silver-containing Hydrofiber dressing. Wound Repair Regen. 2004;12:288-94.
19. Silver S, Phung LT. Bacterial heavy metal resistance: new surprises. Annu Rev Microbiol. 1996:50:753-89.

20. Catauro M, Raucci MG, De Gaetano FD, Marotta A. Antibacterial and bioactive silver-containing $\mathrm{Na}_{2} \mathrm{O} \times \mathrm{CaO} \times 2 \mathrm{SiO}_{2}$ glass prepared by solgel method. J Mater Sci Mater Med. 2004;15:831-7.

21. Crabtree JH, Burchette RJ, Siddiqi RA, Huen IT, Handott LL, Fishman A. The efficacy of silver-ion implanted catheters in reducing peritoneal dialysis-related infections. Perit Dial Int. 2003;23:368-74.

22. Das R, Gang S, Nath SS. Preparation and antibacterial activity of silver nanoparticles. J Biomater Nanobiotechnol. 2011;2:472-5.

23. Aramwit P, Bang N, Ratanavaraporn J, Ekgasit JS. Green synthesis of silk sericin-capped silver nanoparticles and their potent anti-bacterial activity. Nano Res Lett. 2014;9:79.

24. Vigneshwaran N, Nachane RP, Balasubramanya RH, Varadarajan PV. A novel one-pot 'green'synthesis of stable silver nanoparticles using soluble starch. Carbohydr Res. 2006;341:2012-8.

25. Shin Y, Bae IT, Exarhos GJ. Green approach for self-assembly of platinum nanoparticles into nanowires in aqueous glucose solutions. Colloids Surf A. 2009;348:191-5.

26. Zhang Q, Li N, Goebl J, Lu Z, Yin Y. A systematic study of the synthesis of silver nanoplates: is citrate a "magic" reagent? J Am Chem Soc. 2011:133:18931-9.

27. Roldán MV, Pellegri N, de Sanctis O. Electrochemical method for Ag-PEG nanoparticles synthesis. J Nanopart. 2013;2013:524150.

28. Sotiriou GA, Pratsinis SE. Antibacterial activity of nanosilver ions and particles. Environ Sci Technol. 2010;44:5649-54.

29. Sotiriou GA, Teleki A, Camenzind A, Krumeich F, Meyer A, Panke S, Pratsinis SE. Nanosilver on nanostructured silica: antibacterial activity and Ag surface area. Chem Eng J. 2011;170:547-54.

30. Abou El-Nour KMM, Eftaiha A, Al-Warthan A, Ammar RAA. Synthesis and applications of silver nanoparticles. Arab J Chem. 2010:3:135-40.

31. Tien DC, Tseng KH, Liao CY, Huang JC, Tsung TT. Discovery of ionic silver in silver nanoparticle suspension fabricated by arc discharge method. J Alloys Compd. 2008:463:408-11.

32. Asanithi P, Chaiyakun S, Limsuwan P. Growth of silver nanoparticles by DC magnetron sputtering. J Nanomater. 2012;2012:963609.

33. Zhang W, Qiao X, Chen J. Synthesis of silver nanoparticles-effects of concerned parameters in water/oil microemulsion. Mater Sci Eng B. 2007;142:1-15.

34. Wright R, Zhang Q, Kirby P. Synthesis of silver nano particles and fabrication of aqueous Ag inks for inkjet printing. Mater Chem Phys. 2011;129:1075-80.

35. Logaranjan K, Raiza AJ, Gopinath SCB, Chen Y, Pandian K. Shape- and size-controlled synthesis of silver nanoparticles using Aloe vera plant extract and their antimicrobial activity. Nano Res Lett. 2016;11:520.

36. Tippayawat P, Phromviyo N, Boueroy P, Chompoosor A. Green synthesis of silver nanoparticles in aloe vera plant extract prepared by a hydrothermal method and their synergistic antibacterial activity. Peer J. 2016:4:e2589.

37. Moosa AA, Ridha AM, Al-Kaser M. Process parameters for green synthesis of silver nanoparticles using leaves extract of Aloe vera plant. Int Multi Curr Res. 2015;3:966-75.

38. Sreekanth TVM, Ravikumar S, Lee YR. Good use of fruit wastes: ecofriendly synthesis of silver nanoparticles, characterization BSA protein binding studies. J Mol Recogn. 2015:29:253-9.

39. Kumar V, Singh DK, Mohan S, Hasan SH. Photo induced biosynthesis of silver nanoparticles using aqueous extract of Erigeron bonariensis and its catalytic activity against Acridine orange. J Photochem Photobiol B. 2015:55:39-50.

40. Jelin FJ, Kumar SS, Malini M, Vanaja M, Annadurai G. Environmentassisted green approach AgNPs by nutmeg (Myristica fragrans): inhibition potential accustomed to pharmaceuticals. Euro J Biomed Pharm Sci. 2015;2:258-74.

41. Ajitha B, Reddy YAK, Reddy PS. Biosynthesis of silver nanoparticles using Momordica charantia leaf broth: evaluation of their innate antimicrobial and catalytic activities. J Photoch Photobio B. 2015:146:1-9.

42. Chowdhury $\mathbb{H}$, Ghosh S, Roy M, Naskar MK. Green synthesis of waterdispersible silver nanoparticles at room temperature using green carambola (star fruit) extract. J SolGel Sci Technol. 2015;73:199-207. 
43. Kumar B, Smita K, Cumbal L, Debut A. Green synthesis of silver nano particles using Andean blackberry fruit extract. Saudi J Biol Sci. 2017:24:45-50.

44. Kumar B, Angulo Y, Smita K, Cumbal L, Debut A. Capuli cherry-mediated green synthesis of silver nanoparticles under white solar and blue LED light. Particuology. 2016;24:123-8.

45. Mohapatra B, Kuriakose S, Mohapatra S. Rapid green synthesis of silver nanoparticles and nanorods using Piper nigrum extract. J Alloy Compd. 2015;637:119-26.

46. Amooaghaie R, Saeri MR, Azizi M. Synthesis, characterization and biocompatibility of silver nanoparticles synthesized from Nigella sativa leaf extract in comparison with chemical silver nanoparticles. Ecotoxicol Environ Saf. 2015;120:400-8.

47. Pavani KV, Gayathramma K. Synthesis of silver nanoparticles using extracts of Calotropis gigantean flowers. Int J Res Pharm Nano Sci. 2015;4:236-40.

48. Raj DR, Prasanth S, Vineeshkumar TV, Sundarsanakumar C. Surface plasmon resonance based fiber optic dopamine sensor using green synthesized silver nanoparticles. Sen Act B Chem. 2016;224:600-6.

49. Kamachandran K, Kalpana D, Sathishkumar Y, Lee YS, Ravichandran K, Kumar GG. A facile green synthesis of silver nanoparticles using Piper betle biomass and its catalytic activity toward sensitive and selective nitrite detection. J Ind Eng Chem. 2015;35:29-35.

50. Vennila M, Prabha N. Plant mediated green synthesis of silver nano particles from the plant extract of Morinda tinctoria and its application in effluent water treatment. Int J ChemTech Res. 2015;7:2993-9.

51. Meena RK, Chouhan N. Biosynthesis of silver nanoparticles from plant (fenugreek seeds) reducing method and their optical properties. Res J Rec Sci. 2015:4:47-52.

52. Sreekanth TVM, Jung M, Eom I. Green synthesis of silver nanoparticles, decorated on graphene oxide nanosheets and their catalytic activity. Appl Surf Sci. 2015;361:102-6.

53. Suarez-Cerda J, Alonso-Nunez G, Espinoza-Gomez H, Flores-Lopez LZ. Synthesis, kinetics and photocatalytic study of "ultra-small" Ag-NPs obtained by a green chemistry method using an extract of Rosa 'Andeli' double delight petals. J Colloid Interface Sci. 2015;458:169-77.

54. Tahir K, Nazir S, Li B, Khan AU, Khan ZUH, Ahmad A, Khan FU. An efficient photo catalytic activity of green synthesized silver nanoparticles using Salvadora persica stem extract. Separ Puri Technol. 2015;150:316-24

55. Ali M, Kim B, Belfield KD, Norman D, Brennan M, Ali GS. Green synthesis and characterization of silver nanoparticles using Artemisia absinthium aqueous extract-a comprehensive study. Mat Sci Eng C. 2016:58:359-65

56. Barbinta-Patrascu ME, Badea N, Ungureanu C, Constantin M, Pirvu C, Rau I. Silver-based biohybrids "green" synthesized from Chelidonium majus L. Opt Mater. 2016;56:94-9.

57. Babu SA, Prabu HG. Synthesis of AgNPs using the extract of Calotropis procera flower at room temperature. Mat Lett. 2011;65:1675-7.

58. Bogireddy NKR, Kumar HAK, Mandal BK. Biofabricated silver nanoparticles as green catalyst in the degradation of different textiles dyes. J Environ Chem Eng. 2016;4:56-64.

59. Edison TNJI, Lee YR, Sethuraman MG. Green synthesis of silver nanoparticles using Terminalia cuneata and its catalytic action in reduction of direct yellow-12 dye. Spectrochim Acta Mol Biomol Spectrosc. 2016;161:122-9.

60. Khan ZUH, Khan A, Shah A, Wan P, Chen Y, Khan GM, Khan AU, Tahir K, Muhammad N, Khan HU. Enhanced photocatalytic and electrocatalytic applications of green synthesized silver nanaoparticles. J Mol Liq. 2016;220:248-57.

61. Ahmad A, Wei Y, Syed F, Khan S, Khan GM, Tahir K, Khan AU, Raza M, Khan FU, Yuan Q. Isatis tinctoria mediated synthesis of amphotericin B-bound silver nanoparticles with enhanced photo induced antileishmanial activity: a novel green approach. J Photochem Photobiol B Biol. 2016;161:17-24

62. Velmurugan P, Shim J, Kim HW, Lim J, Kim SA, Seo Y, Kim J, Kim K, Oh B. Bio-functionalization of cotton, silk, and leather using different in situ silver nanoparticle synthesis modules, and their antibacterial properties. Res Chem Intermed. 2016. https://doi.org/10.1007/s11164-016-2481-3.
63. Chouhan N, Meena RK. Biosynthesis of silver nanoparticles using Trachyspermum ammi and evaluation of their antibacterial activities. Int J Pharma Biol Sci. 2015;62:1077-86.

64. Ali K, Ahmed B, Dwivedi S, Saquib Q, Al-khedhairy AA, Musarrat J. Microwave accelerated green synthesis of stable silver nanoparticles with Eucalyptus globulus leaf extract and their antibacterial and antibiofilm activity on clinical isolates. PLoS ONE. 2015;10:e0131178.

65. Zia F, Ghafoor N, lqbal M, Mehboob S. Green synthesis and characterization of silver nanoparticles using Cydonia oblong seed extract. Appl Nanosci. 2016;6:1023.

66. Devi TA, Ananthi N, Amaladhas TP. Photobiological synthesis of noble metal nanoparticles using Hydrocotyle asiatica and application as catalyst for the photodegradation of cationic dyes. J Nanostruture Chem. 2016;6:75-92.

67. Manjamadha VP, Muthukumar K. Ultrasound assisted synthesis of silver nanoparticles using weed plant. Bioprocess Biosyst Eng. 2016;39:401-11.

68. Basu S, Maji P, Ganguly J. Rapid green synthesis of silver nanoparticles by aqueous extract of seeds of Nyctanthes arbor-tristis. Appl nanosci. 2016;6:1-5.

69. Sedaghat S, Agbolag AE, Bagheriyan S. Biosynthesis of silver nanoparticles using pennyroyal water extract as a green route. J Nanostrut Chem. 2016;6:25-7.

70. Perugu S, Nagati V, Bhanoori M. Green synthesis of silver nanoparticles using leaf extract of medicinally potent plant Saraca indica: a novel study. Appl Nanosci. 2016;6:747-53.

71. Edison TNJl, Apchudan R, Lee YR. Optical sensor for dissolved ammonia through the green synthesis of silver nanoparticles by fruit extract of Terminala chebula. J Clust Sci. 2016;27:683-90.

72. Cicek S, Gungor AA, Adiguzel A, Nadaroglu H. Biochemical evaluation and green synthesis of nano silver using peroxidase from Euphorbia (Euphorbia amygdaloides) and its antibacterial activity. J Chem. 2015;486948:7.

73. Anandalakshmi K, Venugobal J, Ramasamy V. Characterization of silver nanoparticles by green synthesis method using Pedalium murex leaf extract and their antibacterial activity. Appl Nanosci. 2016;6:399-408.

74. Alishah H, Seyedi SP, Ebrahimipour SY, Esmaeili-Mahani S. A green approach for silver nanoparticles using root extract of Chelidonium majus: characterization and Antibacterial evaluation. J Cluster Sci. 2016:27:421-9.

75. Jadhav K, Dhamecha D, Dalvi B, Patil M. Green synthesis of silver nanoparticles using Salacia chinensis: characterization and its antibacterial activity. Part Sci Technol. 2015;33:445-55.

76. Ramamurthi V, Geetha S, Prabhu S. Synthesis, characterization and antibacterial activity of silver nanoparticles from Tamarindus indica (L.) seed coat extract. J Chem Pharm Res. 2015;7:1022-32.

77. Paul B, Bhuyan B, Purkayastha DD, Dhar SS. Photoctalytic and antibacterial activities of gold and silver nanoparticles synthesized using biomass of Parkia roxburghii leaf. J Photochem Photobiol B. 2016;154:1-7.

78. Shanmugam C, Sivasubramanian G, Parthasarathi BK, Baskaran K, Balachander R, Parameswaran VR. Antimicrobial, free radical scavenging activities and catalytic oxidation of benzyl alcohol by nano-silver synthesized from the leaf extract of Aristolochia indica L.: a promenade towards sustainability. Appl Nanosci. 2016;6:711.

79. Karthik R, Hou Y, Chen S, Elangovan A, Ganesan M. Eco-friendly synthesis of Ag-NPs using Cerasus serrulata plant extract-its catalytic, electrochemical reduction of 4-NPh and antibacterial activity. J Ind Eng Chem. 2016;37:330-9.

80. Parlinska-Wojtan M, Kus-Liskiewicz M, Depciuch J, Sadik O. Green synthesis and antibacterial effects of aqueous colloidal solutions of silver nanoparticles using camomile terpenoids as a combined reducing and capping agent. Bioprocess Biosyst Eng. 2016;39:1213-23.

81. Ocsoy I, Temiz M, Celik C, Altinsoy B, Yilmaz V, Duman F. A green approach for formation of silver nanoparticles on magnetic graphene oxide and highly effective antimicrobial activity and reusability. J Mol Liq. 2017;227:147-52.

82. Swamy MK, Akhtar MS, Mohanty SK, Sinniah UR. Synthesis and characterization of silver nano particles using fruit extract of Momordica cymbalaria and assessment of their in vitro antimicrobial, antioxidant and cytotoxicity activities. Spectrochim Acta A Mol Biomol Spectrosc. 2015;151:939-44. 
83. Pugazhendhi S, Kirubha E, Palanisamy PK, Gopalakrishnan R. Synthesis and characterization of silver nanoparticles from Alpinia calcarata by green approach and its applications in bactericidal and nonlinear optics. Appl Surf Sci. 2015;357:1801-8.

84. Verma DK, Hasan SH, Banik RM. Photo-catalyzed and phyto-mediated rapid green synthesis of silver nanoparticles using herbal extract of Salvinia molesta and its antimicrobial efficacy. J Photochem Photobiol B. 2016;155:51-9.

85. Bhakya S, Muthukrishnan S, Sukumaran M, Muthukumar M. Biogenic synthesis of silver nanoparticles and their antioxidant and antibacterial activity. Appl Nanosci. 2016:6:755.

86. Harshiny M, Matheswaran M, Arthanareeswaran G, Kumaran S, Rajasree S. Enhancement of antibacterial properties of silver nanoparticles-ceftriaxone conjugate through Mukia maderaspatana leaf extract mediated synthesis. Ecotoxicol Environ Saf. 2015;121:135-41.

87. Nayak D, Ashe S, Rauta PR, Kumari M, Nayak B. Bark extract mediated green synthesis of silver nanoparticles: evaluation of antimicrobial activity and antiproliferative response against osteosarcoma. Mater Sci Eng, C. 2015;58:44-52

88. Ahmed S, Saifullah Ahmad M, Swami BL, Ikram S. Green synthesis of silver nanoparticles using Azadirachta indica aqueous leaf extract. J Rad Res Appl Sci. 2016:9:1-7.

89. Latha M, Priyanka M, Rajasekar P, Manikandan R, Prabhu NM. Biocompatibility and antibacterial activity of the Adathoda vasica Linn extract mediated silver nanoparticles. Microb Pathog. 2016;93:88-94.

90. Kolya H, Maiti P, Pandey A, Tripathy T. Green synthesis of silver nanoparticles with antimicrobial and azo dye (Congo red) degradation properties using Amaranthus gangeticus Linn leaf extract. J Anal Sci Technol. 2015:6:33.

91. Allafchian AR, Mirahmadi-Zare SZ, Jalali SAH, Hashemi SS, Vahabi MR. Green synthesis of silver nanoparticles using Phlomis leaf extract and investigation of their antibacterial activity. J Nanostruct Chem. 2016:6:129-35.

92. Yugandhar P, Haribabu R, Savithramma N. Synthesis, characterization and antimicrobial properties of green-synthesised silver nanoparticles from stem bark extract of Syzygium alternifolium (Wt.) Walp. 3. Biotech 2015:5:1031-9.

93. Moyo M, Gomba M, Nharingo T. Afzelia quanzensis bark extract for green synthesis of silver nanoparticles and study of their antibacterial activity. Int J Ind Chem. 2015;6:329-38.

94. Karunakaran G, Jagathambal M, Gusev A, Kolesnikov E, Mandal AR, Kuznetsov D. Allamanda cathartica flower's aqueous extract- mediated green synthesis of silver nanoparticles with excellent antioxidant and antibacterial potential for biomedical application. Mat Res Soc Commun. 2016;6:41-6.

95. Kokila T, Ramesh PS, Geetha D. Biosynthesis of AgNPs using Carica Papaya peel extract and evaluation of its antioxidant and antimicrobial activities. Ecotoxicol Environ Saf. 2016;134:467-73.

96. El-Sherbiny IM, El-Shibiny A, Salih E. Photo-induced green synthesized and anti-microbial efficacy of poly ( $\boldsymbol{\varepsilon}$-caprolactone)/curcumin/grape leaf extract- silver hybrid nanoparticles. J Photochem Photobiol B. 2016;160:355-63.

97. Sengottaiyan A, Mythili R, Selvankumar T, Aravinthan A, Kamala-Kannan S, Manoharan K, Thiyagarajan P, Govarthanan M, Kim J. Green synthesis of silver nanoparticles using Solanum indicum $\mathrm{L}$. and their antibacterial, splenocyte cytotoxic potentials. Res Chem Intermed. 2016;42:3095-103.

98. Devadiga A, Shetty KV, Saidutta MB. Timber industries waste-teak (TeCtona grandis Linn.) mediated synthesis of antibacterial silver nanoparticles. Int Nano Lett. 2015;5:205-14.

99. Sowmyyan T, Lakshmi GV. Green synthesis and characterization of anti-microbial and catalytic silver nanoparticles using Soymida febrifuga aqueous leaf extract. World J Pharm Pharm Sci. 2015:5:786-805.

100. Sundararajan B, Mahendran G, Thamaraiselvi R, Ranjitha Kumari BD. Biological activities of synthesized silver nanoparticles from Cardiospermum halicacabum L. Bull Mater Sci. 2015;39:423-31.

101. Jadhav K, Dhamecha D, Bhattacharya D, Patil M. Green and ecofriendly synthesis of silver nanoparticles: characterization, biocompatibility studies and gel formulation for treatment of infections in burns. J Photochem Photobiol B. 2016;155:109-15.

102. Rao NH, Lakshmidevi N, Pammi CVN, Kollu P, Ganapaty S, Lakshmi P. Green synthesis of silver nanoparticles using methanolic root extracts of Diospyros paniculata and their antimicrobial activities. Mater Sci Eng C Mater Biol Appl. 2016;62:553-7.

103. Kanchana R, Zantye P. Plant-mediated synthesis of silver nanoparticles with diverse applications. Asian J Pharm Clin Res. 2016;9:1124-8.

104. Singh D, Rawat D, Isha B. Microwave-assisted synthesis of silver nanoparticles from Origanum majorana and Citrus sinensis leaf and their antibacterial activity: a green chemistry approach. Bioresour Bioprocess. 2016;3:14.

105. Krishna IM, Reddy GB, Veerabhadram G, Madhusudhan A. Eco-friendly green synthesis of silver nanoparticles using Salmalia malabarica: synthesis, characterization, antimicrobial, and catalytic activity studies. Appl Nonosci. 2016;6:681.

106. Bose D, Chatterjee S. Biogenic synthesis of silver nanoparticles using guava (Psidium guajava) leaf extract and its antibacterial activity against Pseudomonas aeruginosa. Appl Nanosci. 2016;6:895.

107. Balamanikandan T, Balaji S, Pandirajan J. Biological Synthesis of silver nanoparticles by using onion (Allium cepa) extract and their antibacterial and antifungal activity. World App Sci J. 2015;33:939-43.

108. Awad MA, Mekhamer WK, Merghani NM, Hendi AA, Ortashi KMO, Al-Abbas F, Eisa NE. Green synthesis, characterization and Antibacterial activity of silver/polystyrene nanocomposite. J Nanomater. 2015:943821:6.

109. Ahmed MJ, Murtaza G, Mehmood A, Bhatti TM. Green synthesis of silver nanoparticles using leaves extract of Skimmia laureola: characterization and anti-bacterial activity. Mater Lett. 2015;153:10-3.

110. Elangovan K, Elumalai D, Anupriya S, Shenbhagaramam R, Kaleena PK, Murugesan K. Phyto mediated biogenic synthesis of silver nanoparticles using leaf extract of Andrographis echioides and its bio-efficacy on anticancer and antibacterial activities. J Photochem Photobiol, B. 2015;151:118-24.

111. Ali SG, Khan HM, Jalal M, Ansari MA, Mahdi AA, Ahmad MK. Green synthesis of silver nanoparticles using the leaf extract of Putranjiva roxburghii wall. and their antimicrobial activity. Asian J Pharma Clin Res. 2015;8:335-8

112. Nalvolthula R, Merugu R, Rudra MPP. Phytochemical analysis; synthesis; antitumor and antimicrobial activity of silver nanoparticles using flower extracts of Ixora coccinea. Inter J Chem Tech Res. 2015;7:2374-80.

113. Ramesh PS, Kokila T, Geetha D. Plant mediated green synthesis and antibacterial activity of silver nanoparticles using Emblica officinalis fruit extract. Spectrochim Acta Mol Biomol Spectrosc. 2015;142:339-43.

114. Nayak D, Ashe S, Rauta PR, Nayak B. Biosynthesis, characterization and antimicrobial activity of silver nanoparticles using Hibiscus rosa-sinensispetals extracts. IET Nanobiotechnol. 2015;9:288-93.

115. Govindarajan M, Rajeswary M, Veerakumar K, Muthukumaran U, Hoti SL, Mehlhorn H, Barnard DR, Benell G. Novel synthesis of silver nanoparticles using Bauhinia variegata: a recent eco-friendly approach for mosquito control. Parasitol Res. 2016;115:723-33.

116. Panneerselvam C, Murugan K, Roni M, Aziz AT, Suresh U, Rajaganesh R, Madhiyazhagan P, Subramaniam J, Dinesh D, Nicoletti M, Higuchi A, Alarfaj AA, Munusamy MA, Kumar S, Desneux N, Benelli G. Fernsynthesized nanoparticles in the fight against malaria: LC/MS analysis of Pteridium aquilinum leaf extract and biosynthesis of silver nanoparticles with high mosquitocidal and antiplasmodial activity. Parasitol Res. 2016;115:997-1013.

117. Murugan K, Labeeba MA, Panneerselvam C, Dinesh D, Suresh U, Subramaniam J, Madhiyazhagan P, Hwang J, Wang L, Nicoletti M, Benelli G. Aristolochia indica green synthesized silver nanoparticles: a sustainable control tool against the malaria vector Anopheles stephensi. Res Vet Sci. 2015;102:127-35.

118. Muthukumaran U, Govindarajan M, Rajeswary M. Green synthesis of silver nanoparticles from Cassia roxburghii-a most potent power for mosquito control. Parasitol Res. 2014;114:4385-95.

119. Govindarajan M, Rajeswary M, Veerakumar K, Muthukumaran K, Hoti SL, Benelli G. Green synthesis and characterization of silver nanoparticles fabricated using Anisomeles indica: mosquitocidal potential against malaria, dengue and Japanese encephalitis vectors. Exp Parasitol. 2016;161:40-7.

120. Suman TY, Rajasree SR, Jayaseelan C, Mary R, Gayathri S, Aranganathan L, Remya RR. GC-MS analysis of bioactive components and biosynthesis of silver nanoparticles using Hybanthus enneaspermus at room 
temperature evaluation of their stability and its larvicidal activity. Environ Sci Pollut Res. 2016;23:2705-14.

121. Sigamioney M, Shaik S, Govender P, Krishna SBN, Sershen. African leafy vegetables as bio-factories for silver nanoparticles: a case study on Amaranthus dubius C. Mart. Ex Thell S Afr J Bot. 2016;103:230-40.

122. Sreekanth TVM, Pandurangan M, Jung M, Lee YR, Eom I. Eco-friendly decoration of graphene oxide with green synthesized silver nanoparticles: cytotoxic activity. Res chem Intermediat. 2016;42:5665-76.

123. Varghese A, Anandhi P, Arunadevi R, Boovisha A, Sounthari P, Saranya J, Parameswari K, Chitra S. Satin leaf (Chrysophyllum oliviforme) extract mediated green synthesis of silver nanoparticles: antioxidant and anticancer activities. JPSR. 2015;7:266-73.

124. Mata R, Nakkala JR, Sadras SR. Catalytic and biological activities of green silver nanoparticles synthesized from Plumeria alba (frangipani) flower extract. Mater Sci Eng C. 2015:51:216-25.

125. Nalavothula R, Alwala J, Nagati VB, Manthurpadigya PR. Biosynthesis of silver nanoparticles using Impatiens balsamina leaf extracts and its characterization and cytotoxic studies using human cell lines. Inter J Chem Tech Res. 2015;7:2460-8.

126. Parveen M, Ahmad F, Malla AM, Azaza S. Microwave-assisted green synthesis of silver nanoparticles from Fraxinus excelsior leaf extract and its antioxidant assay. Appl Nanosci. 2016;6:267-76.

127. Priya RS, Geetha D, Ramesh PS. Antioxidant activity of chemically synthesized AgNPs and biosynthesized Pongamia pinnata leaf extract mediated AgNPs—a comparative study. Ecotoxicol Environ Saf. 2015;134:308-18

128. Beg M, Maji A, Mandal AK, Das S, Aktara MN, Jha PK, Hossain M. Green synthesis of silver nanoparticles using Pongamia pinnata seed: characterization, antibacterial property, and spectroscopic investigation of interaction with human serum albumin. J Mol Recognit. 2017;30:e2565.

129. Rajan A, Vilas V, Philip D. Catalytic and antioxidant properties of biogenic silver nanoparticles synthesized using Areca catechu nut. J Mol Liq. 2015;207:231-6.

130. Arunachalam K, Shanmuganathan B, Sreeja PS, Parimelazhagan T. Phytosynthesis of silver nanoparticles using the leaves extract of Ficus talboti king and evaluation of antioxidant and antibacterial activities. Environ Sci Pollut Res. 2015;22:18066-75.

131. Srinithya B, Kumar VV, Vadivel V, Pemaiah B, Anthony SP, Muthuraman MS. Synthesis of biofunctionalized AgNPs using medicinally important Sida cordifolia leaf extract for enhanced antioxidant and anticancer activity. Mater Lett. 2016;170:101-4.

132. Sriranjani R, Srinthiya B, Vadivel V, Pemaiah B, Anthony SP, Sivasubramanian A, Muthuraman MS. Silver nanoparticles synthesis using Clerodendrum phlomidis leaf extract and preliminary investigation of its antioxidant and anticancer activity. J Mol Liq. 2016;220:926-30.

133. Lateef A, Azeez MA, Asafa TB, Yakeen TA, Akinboro A, Oladipo LC, Azeez L, Ojo SA, Gueguim-Kana EB, Beukes LS. Cocoa pod husk extract-mediated biosynthesis of silver nanoparticles: its antimicrobial, antioxidant and larvicidal activities. J Nanostruct Chem. 2016;6:159-69.

134. Kumar B, Smita K, Cumbal L, Debut A. Ficus carica (Fig) fruit mediated green synthesis of silver nanoparticles and its antioxidant activity: a comparison of thermal and ultrasonication approach. Bio Nano Sci. 2016;6:15-21.

135. Fatimah I. Green synthesis of silver nanoparticles using extract of Parkia speciosa Hassk pods assisted by microwave irradiation. J Adv Res. 2016;7:961-9

136. Vijay Kumar PPN, Pammi SVN, Kollu P, Satyanarayana KVV, Shameem $\cup$. Green synthesis and characterization of silver nanoparticles using Boerhaavia diffusa plant extract and their anti bacterial activity. Ind Crop Prod. 2014:52:562-6.

137. Karatoprak GS, Aydin G, Altinsoy B, Altinkaynak C, Kos M, Ocsoy I. The Effect of Pelargonium endlicherianum Fenzl. root extracts on formation of nanoparticles and their antimicrobial activities. Enzy Micro Technol. 2017:97:21-6

138. Jagtap UB, Bapat BA. Green synthesis of silver nanoparticles using Artocarpus heterophyllus Lam. Seed extract and its antibacterial activity. Ind Crop Prod. 2013;46:132-7.

139. Muthukrishnan S, Bhakya S, Senthil Kumar T, Rao MV. Biosynthesis, characterization and antibacterial effect ofplant-mediated silver nanoparticles using Ceropegia thwaitesii-Anendemic species. Ind Crop Prod. 2015:63:119-24
140. Niraimathi KL, Sudha V, Lavanya R, Brindha P. Biosynthesis of silver nanoparticles using Alternanthera sessilis (Linn.) extract and their antimicrobial, antioxidant activities. Coll Surf B Biointerface. 2013;102:288-91.

141. Lee JH, Lim JM, Velmurugan P, Park YJ, Park YJ, Bang KS, Oh BT. Photobiologic-mediated fabrication of silver nanoparticles with antibacterial activity. J Photochem Photobiol B Biol. 2016;162:93-9.

142. Swamy MK, Sudipta KM, Jayanta K, Balasubramanya S. The green synthesis, characterization, and evaluation of the biological activities of silver nanoparticles synthesized from Leptadenia reticulata leaf extract. Appl Nanosci. 2015;5:73-81.

143. Wang L, Xu H, Gu L, Han TT, Wang S, Meng FB. Bioinspired synthesis, characterization and antibacterial activity of plant-mediated silver nanoparticles using purple sweet potato root extract. Mat Technol. 2016;31:437-42.

144. Moldovan B, David L, Achim M, Clichici S, Filip GA. A green approach to phytomediated synthesis of silver nanoparticles using Sambucus nigra L. fruits extract and their antioxidant activity. J Mol Liq. 2016;221:271-8.

145. Rajakumar G, Gomathi T, Thiruvengadam M, Rajeswari VD, Kalpana VN, Chung IM. Evaluation of anti-cholinesterase, antibacterial and cytotoxic activities of green synthesized silver nanoparticles using from Millettia pinnata flower extract. Micro Pathol. 2017;103:123-8.

146. Ahmad A, Wei Y, Syed F, Tahir K, Rehman AU, Khan A, Ullah S, Yuan Q. The effects of bacteria-nanoparticles interface on the antibacterial activity of green synthesized silver nanoparticles. Micro Pathol. 2017;102:133-42.

147. Dong C, Cao C, Zhang X, Zhan Y, Wang X, Yang X, Zhou K, Xiao X, Yuan B. Wolfberry fruit (Lycium barbarum) extract mediated novel route for the green synthesis of silver nanoparticles. Optik. 2017;130:162-70.

148. Dhayalan M, Denison MIJ, Jegadeeshwari AL, Krishnan K, Gandhi NN. In vitro antioxidant, antimicrobial, cytotoxic potential of gold and silver nanoparticles prepared using Embelia ribes. Nat Prod Res. 2017;31:465-8.

149. Maria BS, Devadiga A, Kodialbail VS, Saidutta MB. Synthesis of silver nanoparticles using medicinal Zizyphus xylopyrus bark extract. Appl Nanosci. 2015;5:755-62.

150. Kumar CG, Mamidyala SK, Das B, Sridhar B, Devi GS, Karuna MS. Synthesis of biosurfactant-based silver nanoparticles with purified rhamnolipids isolated from Pseudomonas aeruginosa BS-161R. J Microbiol Biotechnol. 2010;20:1061-8.

151. Kiran GS, Sabu A, Selvin J. Synthesis of silver nanoparticles by glycolipid biosurfactant produced from marine Brevibacterium casei MSA19. J Biotechnol. 2010;148:221-5.

152. Deepak V, Umamaheshwaran PS, Guhan K, Nanthini RA, Krithiga B, Jaithoon NMH, Gurunathan S. Synthesis of gold and silver nanoparticles using purified URAK. Coll Surf B Biointerface. 2011;86:353-8.

153. Liu C, Yang D, Wang Y, Shi J, Jiang Z. Fabrication of antimicrobial bacterial cellulose - $\mathrm{Ag} / \mathrm{AgCl}$ nanocomposite using bacteria as versatile biofactory. J Nanopart Res. 2012;14:1084-95.

154. Manikprabhu D, Lingappa K. Antibacterial activity of silver nanoparticles against methicillin-resistant Staphylococcus aureus synthesized using model Streptomyces sp. pigment by photo-irradiation method. J Pharm Res. 2013;6:255-60.

155. Sathiyanarayanan G, Kiran GS, Selvin J. Synthesis of silver nanoparticles by polysaccharide bioflocculant produced from marine Bacillus subtilis MSBN17. Coll Surf B Biointerface. 2013;102:13-20.

156. Gopinathan P, Ashok AM, Selvakumar R. Bacterial flagella as biotemplate for the synthesis of silver nanoparticle impregnated bionanomaterial. Appl Surf Sci. 2013;276:717-22.

157. Hosseini-Abari A, Emtiazi G, Ghasemi SM. Development of an ecofriendly approach for biogenesis of silver nanoparticles using spores of Bacillus athrophaeus. World J Microbiol Biotechnol. 2013;29:2359-64.

158. Kanmani P, Lim ST. Synthesis and structural characterization of silver nanoparticles using bacterial exopolysaccharide and its antimicrobial activity against food and multidrug resistant pathogens. Process Biochem. 2013;48:1099-106.

159. Morsy FM, Nafady NA, Abd-Alla MH, Elhady DA. Green synthesis of silver nanoparticles by water soluble fraction of the extracellular polysaccharides/matrix of the cyanobacterium Nostoc commune and its application as a potent fungal surface sterilizing agent of seed crops. Univ J Microbiol Res. 2014;2:36-43. 
160. Farias CBB, Silva AF, Rufino RD, Luna JM, Souza JEG, Sarubbo LA. Synthesis of silver nanoparticles using a biosurfactant produced in low-cost medium as stabilizing agent. Electro J Biotechnol. 2014;17:122-5.

161. Gahlawat G, Shikha S, Chaddha BS, Chaudhuri SR, Mayilraj S, Choudhury AR. Microbial glycolipoprotein-capped silver nanoparticles as emerging antibacterial agents against cholera. Micro Cell Fact. 2016;15:25.

162. Sowani H, Mohite P, Munot H, Shouche Y, Bapat T, Kumar AR, Kulkarni $M$, Zinjarde S. Green synthesis of gold and silver nanoparticles by an actinomycete Gordonia amicalis HS-11: mechanistic aspects and biological application. Process Biochem. 2016;51:374-83.

163. Mendrek B, Chojniak J, Libera M, Trzebicka B, Bernat P, Paraszkiewicz K, Płaza G. Silver nanoparticles formed in bio- and chemical syntheses with biosurfactant as the stabilizing agent. J Disp Sci Technol. 2017:38:1647-55

164. Durán N, Priscyla D, Marcato PD, Alves O, De Souza G, Esposito E. Mechanistic aspects of biosynthesis of silver nanoparticles by several Fusarium oxysporum strains. J Nanobiotechnol. 2005;3:1-7.

165. Ganesh Babu MM, Gunasekaran P. Production and structural characterization of crystalline silver nanoparticles from Bacillus cereus isolate. Coll Surf B. 2009;74:191-5.

166. Kalimuthu K, Babu RS, Venkataraman D, Bilal M, Gurunathan S. Biosynthesis of silver nanocrystals by Bacillus licheniformis. Coll Surf B. 2008;65:150-3.

167. Klaus T, Joerger R, Olsson E, Granqvist CG. Silver-based crystalline nanoparticles, microbially fabricated. Proc Natl Acad Sci USA. 1999;96:13611-4.

168. Nanda A, Saravanan M. Biosynthesis of silver nanoparticles from Staphylococcus aureus and its antimicrobial activity against MRSA and MRSE. Nanomedicine. 2009;5:452-6.

169. Reddy AS, Chen CY, Chen CC, Jean JS, Chen HR, Tseng MJ, Fan CW, Wang JC. Biological synthesis of gold and silver nanoparticles mediated by the bacteria Bacillus subtilis. J Nanosci Nanotechnol. 2010;10:6567-74.

170. Shivaji S, Madhu S, Singh S. Extracellular synthesise of antibacterial silver nanoparticles using psychrophilic bacteria. Process Biochem. 2011:49:830-7.

171. Wei X, Luo M, Li W, Yang L, Liang X, Xu L, Kong P, Liu H. Synthesis of silver nanoparticles by solar irradiation of cell-free Bacillus amyloliquefaciens extracts and $\mathrm{AgNO}_{3}$. Bioresour Technol. 2012;103:273-8.

172. Saravanan M, Vemu AK, Barik SK. Rapid biosynthesis of silver nanoparticles from Bacillus megaterium (NCIM 2326) and their antibacterial activity on multi drug resistant clinical pathogens. Coll Surf B. 2011;88:325-31.

173. Priyadarshini S, Gopinath V, Meera Priyadharsshini N, Mubarak Ali D, Velusamy P. Synthesis of anisotropic silver nanoparticles using novel strain, Bacillus flexus and its biomedical application. Coll Surf B Biointerface. 2013;102:232-7.

174. Das VL, Thomas R, Varghese RT, Soniya EV, Mathew J, Radhakrishnan EK. Extracellular synthesis of silver nanoparticles by the Bacillus strain CS 11 isolated from industrialized area. 3. Biotech. 2014;4:121-6.

175. Singh R, Wagh P, Wadhwani S, Gaidhani S, Kumbhar A, Bellare J, Chopade BA. Synthesis, optimization, and characterization of silver nanoparticles from Acinetobacter calcoaceticus and their enhanced antibacterial activity when combined with antibiotics. Int J Nanomed. 2013:8:4277-90.

176. Gaidhani SV, Raskar AV, Poddar S, Gosavi S, Sahu PK, Pardesi KR, Bhide SV, Chopade BA. Time dependent enhanced resistance against antibiotics and metal salts by planktonic and biofilm form of Acinetobacter haemolyticus MMC8 clinical isolate. Indian J Med Res. 2014;140:665-71.

177. Mouxing F, Qingbiao L, Daohua S, Yinghua L, Ning H, Xu D, Huixuan W, Jiale H. Rapid preparation process of silver nanoparticles by bioreduction and their characterizations. Chin J Chem Eng. 2006;14:114-7.

178. Wang $H$, Chen H, Wang Y, Huang J, Kong T, Lin W, Zhou Y, Lin L, Sin D, Li Q. Stable silver nanoparticles with narrow size distribution non-enzymatically synthesized by Aeromonas sp. SH10 cells in the presence of hydroxyl ions. Curr Nanosci. 2012;8:838-46.

179. Thomas R, Jasim B, Mathew J, Radhakrishnan EK. Extracellular synthesis of silver nanoparticles by endophytic Bordetella sp. Isolated from Piper nigrum and its antibacterial activity analysis. Nano Biomed Eng. 2012;4:183-7.
180. Karthik C, Radha KV. Biosynthesis and characterization of silver nanoparticles using Enterobacter aerogenes: a kinetic approach. Dig J Nanomater Biostruct. 2012;7:1007-14

181. Gurunathan S, Kalishwaralal K, Vaidyanathan R, Deepak V, Pandian SRK, Muniyandi J, Hariharan N, Eom SH. Biosynthesis, purification and characterization of silver nanoparticles using Escherichia coli. Coll Surf B Biointerface. 2009; 74:328-35.

182. Law N, Ansari S, Livens FR, Renshaw JC, Lloyd JR. The formation of nanoscale elemental silver particles via enzymatic reduction by Geobacter sulfurreducens. Appl Environ Microbiol. 2008;4:7090-3.

183. Krishnaraj RN, Berchmans S. In vitro antiplatelet activity of silver nanoparticles synthesized using the microorganism Gluconobacter roseus: an AFM-based study. RSC Adv. 2013;3:8953-9.

184. Seshadri S, Prakash A, Kowshik M. Biosynthesis of silver nanoparticles by marine bacterium, Idiomarina sp. p R58-8. Bull Mater Sci. 2012;35:1201-5.

185. Duraisamy K, Yang SL. Synthesis and characterization of bactericidal silver nanoparticles using cultural filtrate of simulated microgravity grown Klebsiella pneumoniae. Enzyme Microb Technol. 2013;52:151-6.

186. Parikh RY, Singh S, Prasad BLV, Patole MS, Sastry M, Shouche YS. Extracellular synthesis of crystalline silver nanoparticles and molecular evidence of silver resistance from Morganella sp:: towards understanding biochemical synthesis mechanism. Chem Bio Chem. 2008;9:1415-22.

187. Samadi N, Golkaran D, Eslamifar A, Jamalifar H, Fazeli MR, Mohseni FA. Intra/extracellular biosynthesis of silver nanoparticles by an autochthonous strain of Proteus mirabilis isolated from photographic waste. J Biomed Nanotechnol. 2009;5:247-53.

188. Srivastava SK, Constanti M. Room temperature biogenic synthesis of multiple nanoparticles ( $\mathrm{Ag}, \mathrm{Pd}, \mathrm{Fe}, \mathrm{Rh}, \mathrm{Ni}, \mathrm{Ru}, \mathrm{Pt} \mathrm{Co}$, and Li) by Pseudomonas aeruginosa SM1. J Nanopart Res. 2012;14:831-40.

189. Kumar CG, Mamidyala SK. Extracellular synthesis of silver nanoparticles using culture supernatant of Pseudomonas aeruginosa. Coll Surf B Biointerface. 2011:84:462-6.

190. Otaqsara SMT. Biosynthesis of quasi-spherical Ag nanoparticle by Pseudomonas aeruginosa as a bioreducing agent. Eur Phys J Appl Phys. 2011;56:30402.

191. Bai HJ, Yang BS, Chai CJ, Yang GE, Jia WL, Yi ZB. Green synthesis of silver nanoparticles using Rhodobacter sphaeroides. World J Microbiol Biotechnol. 2011;27:2723-8.

192. Chun-Jing C, Hong-Juan B. Biosynthesis of silver nanoparticles using the phototrophic bacteria Rhodopseudomonas palustris and its antimicrobial activity against Escherichia coli and Staphylococcus aureus. Microbiol China. 2010;37:1798-804.

193. Debabov VG, Voeikova TA, Shebanova AS, Shaitan KV, Emel'yanova LK, Novikova LM, Kirpichnikov MP. Bacterial synthesis of silver sulfide nanoparticles. Nanotechnol Russ. 2013;8:269-76.

194. Oves M, Khan MS, Zaidi A, Ahmed AS, Ahmed F, Ahmad E, Sherwani A, OwaisM AzamA. Antibacterial and cytotoxic efficacy of extracellular silver nanoparticles biofabricated from chromium reducing novel OS4 strain of Stenotrophomonas maltophilia. PLoS ONE. 2013;8:e59140.

195. Rajeshkumar S, Malarkodi C, Paulkumar K, Vanaja M, Gnanajobitha G, Annadurai G. Intracellular and extracellular biosynthesis of silver nanoparticles by using marine bacteria Vibrio alginolyticus. Nanosci Nanotechnol. 2013;3:21-5.

196. Narayanan KB, Sakthivel N. Biosynthesis of silver nanoparticles by phytopathogen Xanthomonas oryzae pv. oryzae strain BXO8. J Microbiol Biotechnol. 2013;23:1287-92.

197. Pourali P, Baserisalehi M, Afsharnezhad S, Behravan J, Alavi H, Hosseini A. Biological synthesis of silver and gold nanoparticles by bacteria in different temperatures $\left(37^{\circ} \mathrm{C}\right.$ and $\left.50^{\circ} \mathrm{C}\right)$. J Pure Appl Microbiol. 2012;6:757-63.

198. Pugazhenthiran N, Anandan S, Kathiravan G, Prakash NKU, Crawford S Ashokkumar M. Microbial synthesis of silver nanoparticles by Bacillus sp. J Nanopart Res. 2009;11:1811-5.

199. Shanthi S, Jayaseelan BD, Velusamy P, Vijayakumar S, Chih CT, Vaseeharan B. Biosynthesis of silver nanoparticles using a probiotic Bacillus licheniformis Dahb1 and their antibiofilm activity and toxicity effects in Ceriodaphnia cornuta. Micro Pathog. 2016;93:70-7.

200. Lateef A, Adelere IA, Gueguim-Kana EB, Asafa TB, Beukes LS. Green synthesis of silver nanoparticles using keratinase obtained from a strain of Bacillus safensis LAU 13. Int Nano Lett. 2015;5:29-35. 
201. Wang C, Kim YJ, Singh P, Mathiyalagan R, Jin Y, Yang DC. Green synthesis of silver nanoparticles by Bacillus methylotrophicus, and their antimicrobial activity. Artif Cell Nanomed Biotechnol. 2016:44:1127-32.

202. Kannan N, Mukunthan KS, Balaji S. A comparative study of morphology, reactivity and stability of synthesized silver nanoparticles using Bacillus subtilis and Catharanthus roseus (L.) G. Don. Coll Surf B Biointerface. 2011;86:378-83.

203. Paulkumar K, Rajeshkumar S, Gnanajobitha G, Vanaja M, Malarkodi C, Annadurai $\mathrm{G}$. Biosynthesis of silver chloride nanoparticles using Bacillus subtilis MTCC 3053 and assessment of its antifungal activity. ISRN Nanomaterials. 2013;317963:8.

204. Banu AN, Balasubramanian C, Moorthi PV. Biosynthesis of silver nanoparticles using Bacillus thuringiensis against dengue vector, Aedes aegypti (Diptera: Culicidae). Parasitol Res. 2014;113:311-6.

205. Kalishwaralal K, Deepak V, Pandian SRK, Kottaisamy M, BarathManiKanth S, Kartikeyan B, Gurunathan S. Biosynthesis of silver and gold nanoparticles using Brevibacterium casei. Coll Surf B Biointerface. 2010;77:257-62.

206. Zhang H, Li Q, Lu Y, Sun D, Lin X, Deng X, He N, Zheng S. Biosorption and bioreduction of diamine silver complex by Corynebacterium. J Chem Technol Biotechnol. 2005;80:285-90.

207. Tamboli DP, Lee DS. Mechanistic antimicrobial approach of extracellularly synthesized silver nanoparticles against gram positive and gram negative bacteria. J Hazard Mater. 2013;260:878-84.

208. Fayaz AM, GirilalM Rahman M, Venkatesan R, Kalaichelvan PT. Biosynthesis of silver and gold nanoparticles using thermophilic bacterium Geobacillus stearothermophilus. Process Biochem. 2011;46:1958-62.

209. Dhoondia ZH, Chakraborty H. Lactobacillus mediated synthesis of silver oxide nanoparticles. Nanomater Nanotechnol. 2012;2:1-7.

210. Otari SV, Patil RM, Nadaf NH, Ghosh SJ, Pawar SH. Green synthesis of silver nanoparticles by microorganism using organic pollutant: its antimicrobial and catalytic application. Environ Sci Pollut Res. 2014;21:1503-13.

211. Deepa S, Kanimozhi K, Panneerselvam A. Antimicrobial activity of extracellularly synthesized silver nanoparticles from marine derived actinomycetes. Int J Curr Microbiol Appl Sci. 2013;2:223-30.

212. Juibari MM, Abbasalizadeh S, Jouzani GS, Noruzi M. Intensified biosynthesis of silver nanoparticles using a native extremophilic Ureibacillus thermosphaericus strain. Mater Lett. 2011;65:1014-7.

213. Ingle A, Gade A, Pierrat S, Sönnichsen C, Rai M. Mycosynthesis of silver nanoparticles using the fungus Fusarium acuminatum and its activity against some human pathogenic bacteria. Curr Nanosci. 2008:4:141-4.

214. Ingle A, Rai M, Gade A, Bawaskar M. Fusarium solani: a novel biological agent for the extracellular synthesis of silver nanoparticles. J Nanopart Res. 2009;11:2079-85.

215. Kathiresan K, Manivannan S, Nabeal MA, Dhivya B. Studies on silver nanoparticles synthesized by a marine fungus, Pencillium fellutanum isolated from coastal mangrove sediment. Coll Surf B Biointerface. 2009;71:133-7.

216. Durán N, Marcato PD, De Souza GIH, Alves OL, Esposito E. Antibacterial effect of silver nanoparticles produced by fungal process on textile fabrics and their effluent treatment. J Biomed Nanotechnol. 2007;3:203-8.

217. Vigneshwaran N, Ashtaputre NM, Varadarajan PV, Nachane RP, Paralikar KM, Balasubramanya RH. Biological synthesis of silver nanoparticles using the fungus Aspergillus flavus. Mater Lett. 2007;61:1413-8.

218. Bhainsa KC, D'Souza SF. Extracellular biosynthesis of silver nanoparticles using the fungus Aspergillus fumigatus. Coll Surf B Biointerface. 2006:47:160-4.

219. Li G, He D, Qian Y, Guan B, Gao S, Cui Y, Yokoyama K, Wang L. Fungusmediated green synthesis of silver nanoparticles using Aspergillus terreus. Int J Mol Sci. 2012;13:466-76.

220. Balaji DS, Basavaraja S, Deshpande R, Mahesh DB, Prabhakar BK, Venkataraman A. Extracellular biosynthesis of functionalized silver nanoparticles by strains of Cladosporium cladosporioides fungus. Coll Surf B Biointerface. 2009;68:88-92.

221. Sanghi $R$, Verma P. Biomimetic synthesis and characterisation of protein capped silver nanoparticles. Bioresour Technol. 2009;100:501-4.

222. Ahmad A, Mukherjee P, Senapat S, Mandal D, Khan MI, Kumar R, Sastry M. Extracellular biosynthesis of silver nanoparticles using the fungus Fusarium oxysporum. Coll Surf B Biointerface. 2003;28:313-8.
223. Senapati S, Mandal D, Ahmad A. Fungus mediated synthesis of silver nanoparticles: a novel biological approach. Ind J Phys A. 2004;78A:101-5.

224. Syed A, Saraswati S, Kundu GC, Ahmad A. Biological synthesis of silver nanoparticles using the fungus Humicola sp. and evaluation of their cytoxicity using normal and cancer cell lines. Spectro Acta Part A Mol Biomol Spectros. 2013;114:144-7.

225. Chowdhury S, Basu A, Kundu S. Green synthesis of protein capped silver nanoparticles from phytopathogenic fungus Macrophomina phaseolina (Tassi) Goid with antimicrobial properties against multidrug-resistant bacteria. Nano Res Lett. 2014;9:365.

226. Shaligram NS, Bule A, Bhambure R, Singhal RS, Singh SK, Szakacs G, Pandey A. Biosynthesis of silver nanoparticles using aqueous extract from the compactin producing fungal strain. Process Biochem. 2009;44:939-43.

227. Maliszewska I, Juraszek A, Bielska K. Green synthesis and characterization of silver nanoparticles using ascomycota fungi Penicillium nalgiovense AJ12. J Clust Sci. 2014;25:989-1004.

228. Vigneshwaran N, Kathe AA, Varadarajan PV, Nachane RP, Balasubramanya RH. Biomimetics of silver nanoparticles by white rot fungus, Phaenerochaete chrysosporium. Coll Surf B Interface. 2006;53:55-9.

229. Birla SS, Tiwari WV, Gade AK, Ingle AP, Yadav AP, Rai MK. Fabrication of silver nanoparticles by Phoma glomerata and its combined effect against Escherichia coli, Pseudomonas aeruginosa and Staphylococcus aureus. Lett Appl Microbiol. 2009;43:173-9.

230. Al-Bahrani R, Raman J, Lakshmanan H, Hassan AA, Sabaratnam V. Green synthesis of silver nanoparticles using tree oyster mushroom Pleurotus ostreatus and its inhibitory activity against pathogenic bacteria. Mat Lett. 2017;186:21-5.

231. Vigneshwaran N, Kathe A. Silver-protein (core-shell) nanoparticle production using spent mushroom substrate. Langmuir. 2007;23:7113-7.

232. Mukherjee P, Roy M, Mandal BP, Dey GK, Mukherjee PK, Ghatak J, Tyagi AK, Kale SP. Green synthesis of highly stabilized nanocrystalline silver particles by a non-pathogenic and agriculturally important fungus $T$. asperellum. Nanotechnoloy. 2008;19:1-7.

233. Vahabi K, Mansoori GA, Karimi S. Biosynthesis of silver nanoparticles by fungus Trichoderma reesei (a route for large-scale production of AgNPs). Insci J. 2011;1:65-79.

234. Fayaz M, Tiwary CS, Kalaichelvan PT, Venkatesan R. Blue orange light emission from biogenic synthesized silver nanoparticles using Trichoderma viride. Coll Surf B Biointerfaces. 2010;75:175-8.

235. Kumari M, Pandey S, Giri VP, Bhattacharya A, Shukla R, Mishra A, Nautiyal CS. Tailoring shape and size of biogenic silver nanoparticles to enhance antimicrobial efficacy against MDR bacteria. Microb Pathog. 2017;105:346-55.

236. Chwalibog A, Sawosz E, Hotowy A, Szeliga J, Mitura S, Mitura K, Grodzik M, Orlowski P, Sokolowska A. Visualization of interaction between inorganic nanoparticles and bacteria or fungi. Int J Nanomed. 2010;5:1085-94.

237. Owaid MN, Raman J, Lakshmanan H, Al-Saeedi SSS, Sabaratnam V, Abed IA. Mycosynthesis of silver nanoparticles by Pleurotus cornucopiae var. citrinopileatus and its inhibitory effects against Candida sp. Mater Lett. 2015;153:186-90.

238. Husen A. Gold nanoparticles from plant system: synthesis, characterization and their application. In: Ghorbanpourn M, Manika K, Varma A, editors. Nanoscience and plant-soil systems, vol. 48. Cham: Springer International Publication; 2017. p. 455-79.

239. Hazarika SN, Gupta K, Shamin KNAM, Bhardwaj P, Boruah R, Yadav KK, Naglot A, Deb P, Mandal M, Doley R, Veer V, Baruah I, Namsa ND. Onepot facile green synthesis of biocidal silver nanoparticles. Mat Res Exp. 2016;3:075401. https://doi.org/10.1088/2053-1591/3/7/075401.

240. Reddy NJ, Vali DN, Rani M, Rani SS. Evaluation of antioxidant, antibacterial and cytotoxic effects of green synthesized silver nanoparticles by Piper longum fruit. Mat Sci Eng C. 2014;34:115-22.

241. Puisoa J, Jonkuviene D, Macioniene I, Salomskiene J, Jasutiene I, Kondrotas R. Biosynthesis of silver nanoparticles using lingonberry and cranberry juices and their antimicrobial activity. Coll Surf B Biointerface. 2014;121:214-21.

242. Silver Nanoparticle Properties, Cytodiagnostics Inc. (2017) http://www. cytodiagnostics.com/store/pc/Silver-Nanoparticle-Properties-d11.htm. Accessed 8 Aug 2017. 
243. Mock JJ, Barbic M, Smith DR, Shultz DA, Shultz S. Shape effects in plasmonresonance of individual colloidal silver nanoparticles. J Chem Phys. 2002;116:6755-9.

244. Henglein A. Physicochemical properties of small metal particles in solution: "microelectrode" reactions, chemisorption, composite metal particles, and the atom-to-metal transition. J Phys Chem. 1993;97:5457-71.

245. Henglein A. Colloidal silver nanoparticles: photochemical preparation and interaction with $\mathrm{O} 2, \mathrm{CCl} 4$, and some metal ions. Chem Mater. 1993;10:444-50.

246. Bakshi MS, Possmayer F, Petersen NO. Role of different phospholipids in the synthesis of pearl-necklace-type Gold-Silver bimetallic nanoparticles as bioconjugate materials. J Phys Chem C. 2007;111:14113-24.

247. Kanipandian N, Kannan S, Ramesh R, Subramanian P, Thirumurugan R. Characterization, antioxidant and cytotoxicity evaluation of green synthesized silver nanoparticles using Cleistanthus collinus extract as surface modifier. Mat Res Bull. 2014;49:494-502.

248. Banerjee P, Satapathy P, Mukhopahayay A, Das P. Leaf extract mediated green synthesis of silver nanoparticles from widely available Indian plants: synthesis, characterization, antimicrobial property and toxicity analysis. Bioresour Bioprocess. 2014:1:3.

249. Brayner R. The toxicological impact of nanoparticles. Nanotoday. 2008:3:48-55.

250. Panda KK, Achary VMM, Krishnaveni R, Padhi BK, Sarangi SN, Sahu SN, Panda BB. In vitro biosynthesis and genotoxicity bioassay of silver nanoparticles using plants. Toxicol Vitro. 2011;25:1097-105.

251. Jayasree L, Janakiram P, Madhavi R. Characterization of Vibrio spp. associated with diseased shrimp from culture ponds of Andhra Pradesh (India). J World Aquacult Soc. 2006;37:523-32.

252. Oberdorster E. Manufactured nanomaterials (fullerenes, $C_{60}$ ) induce oxidative stress in the brain of juvenile largemouth bass. Environ Health Perspect. 2004;112:1058-62.

253. Kim S, Ryu DY. Silver nanoparticle-induced oxidative stress, genotoxicity and apoptosis in cultured cells and animal tissues. J Appl Toxicol. 2013;33:78-89.

254. Hackenberg S, Scherzed A, Kessler M, Hummel S, Technau A, Froelich K, Ginzkey C, Koehler C, Hagen R, Kleinsasser N. Silver nanoparticles: evaluation of DNA damage, toxicity and functional impairment in human mesenchymal stem cells. Toxicol Lett. 2011;201:27-33.

255. Samberg ME, Loboa EG, Oldenburg SJ, Monteiro-Riviere NA. Silver nanoparticles do not influence stem cell differentiation but cause minimal toxicity. Nanomedicine. 2012;7:1197-209.

256. Kittler S, Greulich C, Diendorf J, Koller M, Epple M. Toxicity of silver nanoparticles increases during storage because of slow dissolution under release of silver ions. Chem Mater. 2010;22:4548-54.

257. Beer C, Foldbjerg R, Hayashi Y, Sutherland DS, Autrup H. Toxicity of silver nanoparticles-nanoparticle or silver ion? Toxicol Lett. 2012;208:286-92.

258. Cronholm P, Karlsson HL, Hedberg J, Lowe TA, Winnberg L, Elihn K, Wallinder IO, Moller L. Intracellular uptake and toxicity of Ag and CuO nanoparticles: a comparison between nanoparticles and their corresponding metal ions. Small. 2013;9:970-82.

259. Austin B, Austin DA. Bacterial fish pathogens. Diseases of farmed and wild fish. Chichester: Springer-Praxis Publishing Ltd; 1999.

260. Cai JP, Li J, Thompson KD, Li CX, Han HC. Isolation and characterization of pathogenic Vibrio parahaemolyticus from diseased post-larvae of abalone Haliotis diversicolor supertexta. J Basic Microbiol. 2007:47:84-6.

261. Logeswari P, Silambarasan S, Abraham J. Synthesis of silver nanoparticles using plants extract and analysis of their antimicrobial property. J Saudi Chem Soc. 2015;19:311-7.

262. Gliga AR, Skoglund S, Wallinder IO, Fadeel B, Karlsson HL. Size-dependent cytotoxicity of silver nanoparticles in human lung cells: the role of cellular uptake, agglomeration and Ag release. Particle Fibre Toxicol. 2014:11:11-28.

263. Han X, Gelein R, Corson N, Wade-Mercer P, Jiang J, Biswas P, Finkelstein $\mathrm{JN}$, Elder A, Oberdorster $\mathrm{G}$. Validation of an LDH assay for assessing nanoparticle toxicity. Toxicology. 2011;287:99-104.

264. Holder AL, Marr LC. Toxicity of silver nanoparticles at the air-liquid interface. Biomed Res Int. 2013;328934:11.

265. Stebounova L, Guio E, Grassian V. Silver nanoparticles in simulated biological media: a study of aggregation, sedimentation, and dissolution. J Nanopart Res. 2011;13:233-44
266. Carlson C, Hussain SM, Schrand AM, Braydich-Stolle LK, Hess KL, Jones RL, Schlager JJ. Unique cellular interaction of silver nanoparticles: size-dependent generation of reactive oxygen species. J Phys Chem B. 2008;112:13608-19.

267. Liu W, Wu Y, Wang C, Li HC, Wang T, Liao CY, Cui L, Zhou QF, Yan B, Jiang GB. Impact of silver nanoparticles on human cells: effect of particle size. Nanotoxicology. 2010:4:319-30.

268. Wang X, Ji Z, Chang CH, Zhang H, Wang M, Liao YP, Lin S, Meng H, Li R, Sun B, Winkle LV, Pinkerton KE, Zink JI, Xia T, Nel AE. Use of coated silver nanoparticles to understand the relationship of particle dissolution and bioavailability to cell and lung toxicological potential. Small. 2014;10:385-98

269. Li N, Xia T, Nel AE. The role of oxidative stress in ambient particulate matter-induced lung diseases and its implications in the toxicity of engineered nanoparticles. Free Radic Biol Med. 2008;44:1689-99.

270. Liu J, Wang Z, Liu FD, Kane AB, Hurt RH. Chemical transformations of nanosilver in biological environments. ACS Nano. 2012;6:9887-99.

271. Shankar SS, Ahmad A, Sastry M. Geranium leaf assisted biosynthesis of silver nanoparticles. Biotechnol Prog. 2003;19:1627-31.

272. Shankar SS, Rai A, Ahmad A, Sastry M. Rapid synthesis of Au, Ag, and bimetallic Au core-Ag shell nanoparticles using Neem (Azadirachta indica) leaf broth. J Coll Interface Sci. 2004:275:496-502.

273. Zhao G, Stevens SE Jr. Multiple parameters for the comprehensive evaluation of the susceptibility of Escherichia coli to the silver ion. Biometals. 1998;11:27-32.

274. Aymonier C, Schlotterbeck U, Antonietti L, Zacharias P, Thomann R, Tiller JC, Mecking S. Hybrids of silver nanoparticles with amphiphilic hyperbranched macromolecules exhibiting antimicrobial properties. Chem Commun (Camb). 2002;24:3018-9.

275. Kim JS, Kuk E, Yu KN, Kim JH, Park SJ, Lee HJ, Kim SH, Park YK, Park YH, Hwang CY, Kim YK, Lee YS, Jeong DH, Cho MH. Antimicrobial effects of silver nanoparticles. Nanomed Nanotechnol Biol Med. 2007;3:95-101.

276. Allahverdiyev AM, Kon KV, Abamor ES, Bagirova M, Rafailovich M. Coping with antibiotic resistance: combining nanoparticles with antibiotics and other antimicrobial agents. Expert Rev Anti Infect Ther. 2011;9:1035-52

277. Graves JL, Tajkarimi M, Cunningham Q, Campbell A, Nonga H, Harrison SH, Barrick JE. Rapid evolution of silver nanoparticle resistance in Escherichia coli. Front Genet. 2015;6:42.

278. Manivasagan P, Venkatesan J, Senthilkumar K, Sivakumar K, Kim SK. Biosynthesis, antimicrobial and cytotoxic effect of silver nanoparticles using a novel Nocardiopsis sp. MBRC-1. Biomed Res. 2013. https://doi. org/10.1155/2013/287638.

279. Shanmugasundaram T, Radhakrishnan M, Gopikrishnan V, Pazhanimurugan R, Balagurunathan R. A study of the bactericidal, anti-biofouling, cytotoxic and antioxidant properties of actinobacterially synthesised silver nanoparticles. Colloids Surf B Biointerfaces. 2013;111:680-7.

280. Gurunathan S, Han JW, Eppakayala V, Jeyaraj M, Kim J-H. Cytotoxicity of biologically synthesized silver nanoparticles in MDA-MB-231 human breast cancer cells. Biomed Res Int. 2013;287638:9.

281. Kumar SP, Balachandran C, Duraipandiyan V, Ramasamy D, Ignacimuthu S, Al-Dhabi NA. Extracellular biosynthesis of silver nanoparticle using Streptomyces sp. 09 PBT 005 and its antibacterial and cytotoxic properties. Appl Nanosci. 2015;5:169-80.

282. Namasivayam SKR, Prakash P, Kumar G. Anti tumor activity of biologically synthesized silver nanoparticles produced by Lactobacillus acidophilus against HEP2. J Pharm Res. 2011:4:1651-3.

283. Rai M, Yadav A, Gade A. Silver nanoparticles as a new generation of antimicrobials. Biotechnol Adv. 2009;27:76-83.

284. Agnihotri S, Mukherji S, Mukherji S. Size-controlled silver nanoparticles synthesized over the range 5-100 Nm using the same protocol and their antibacterial efficacy. RSC Adv. 2014:4:3974-83.

285. Mendis E, Rajapakse N, Byun HG, Kim SK. Investigation of jumbo squid (Dosidicus gigas) skin gelatin peptides for their in vitro antioxidant effects. Life Sci. 2005;77:2166-78.

286. Dibrov P, Dzioba J, Gosink KK, Hase CC. Chemiosmotic mechanism of antimicrobial activity of $\mathrm{Ag}(+)$ in Vibrio cholerae. Antimicrob Agents Chemother. 2002:46:2668-70

287. Hamouda T, Myc A, Donovan B, Shih A, Reuter JD, Baker JR Jr. A novel surfactant nanoemulsion with a unique non-irritant topical 
antimicrobial activity against bacteria, enveloped viruses and fungi. Microbiol Res. 2000;156:1-7.

288. Sondi I, Salopek-Sondi B. Silver nanoparticles as antimicrobial agent: a case study on E. coli as a model for Gram-negative bacteria. J Coll Interface Sci. 2004;275:177-82.

289. Amro NA, Kotra LP, Wadu-Mesthrige K, Bulychev A, Mobashery S, Liu G. High-resolution atomic force microscopy studies of the Escherichia coli outer membrane: structural basis for permeability. Langmuir. 2000;16:2789-96.

290. Danilczuk M, Lund A, Saldo J, Yamada H, Michalik J. Conduction electron spin resonance of small silver particles. Spectro Acta Part A. 2006;63:189-91.

291. Creighton JA, Blatchford CG, Albrecht MG. Plasma resonance enhancement of Raman scattering by pyridine adsorbed on silver or gold sol particles of size comparable to the excitation wavelength. J Chem Soc Faraday Trans II. 1979;75:790-8.

292. Furno F, Morley KS, Wong B, Sharp BL, Arnold PL, Howdle SM, Roger Bayston R, Brown PD, Winship PD, Reid HJ. Silver nanoparticles and polymeric medical devices: a new approach to prevention of infection? J Antimicrob Chemother. 2004;54:1019-24.

293. Akhavan O, Ghaderi E. Toxicity of graphene and graphene oxide nanowalls against bacteria. ACS Nano. 2010:4:5731-6.

294. Hu W, Peng C, Luo W, Lv M, Li X, Li D, Huang Q, Fan C. Graphene-based antibacterial paper. ACS Nano. 2010;4:4317-23.

295. Xu WP, Zhang LC, Li JP, Lu Y, Li HH, Ma YN, Wang WD, Yu SH. Facile synthesis of silver@graphene oxide nanocomposites and their enhanced antibacterial properties. J Mater Chem. 2011;21:4593-7.

296. Ma J, Zhang J, Xiong Z, Yong Y, Zhao XS. Preparation, characterization and antibacterial properties of silver-modified graphene oxide. J Mater Chem. 2011;21:3350-2.

297. Chaloupka K, Malam Y, Seifalian AM. Nanosilver as a new generation of nanoproduct in biomedical applications. Trends Biotechnol. 2010:28:580-8.

298. Morones JR, Elechiguerra JL, Camacho A, Holt K, Kouri JB, Ramírez JT, Yacaman MJ. The bactericidal effect of silver nanoparticles. Nanotechnol. 2005;16:2346-53.

299. Le AT, Huy PT, Tam PD, Huy TQ, Cam PD, Kudrinskiy AA, Krutyakov YA. Green synthesis of finely-dispersed highly bactericidal silver nanoparticles via modified Tollens technique. Curr Appl Phys. 2010;10:910-6.

300. Tho NTM, An TNM, Tri MD, Sreekanth TVM, Lee JS, Nagajyothi PC, Lee KD. Green synthesis of silver nanoparticles using Nelumbo nucifera seed extract and its antibacterial activity. Acta Chim Slov. 2013;60:673-8.
301. Soenen SJ, Rivera-Gil P, Montenegro JM, Parak WJ, De Smedt SC, Braeckmans K. Cellular toxicity of inorganic nanoparticles: common aspects and guidelines for improved nanotoxicity evaluation. Nano Today. 2011;6:446-65.

302. Nel AE, Madler L, Velegol D, Xia T, Hoek EMV, Somasundaran P, Klaessig F, Castranova V, Thompson M. Understanding biophysicochemical interactions at the nano-bio interface. Nat Mater. 2009:8:543-57.

303. Bolla JM, Alibert-Franco S, Handzlik J, Chevalier J, Mahamoud A, Boyer G, Kieć-Kononowicz K, Pagès JM. Strategies for bypassing the membrane barrier in multidrug resistant Gram-negative bacteria. FEBS Lett. 2011;585:1682-90.

304. Thwala N, Musee M, Nota N. The antibacterial effects of engineered nanomaterials: implications for wastewater treatment plants. J Environ Monit. 2011;13:1164-83.

305. Allahverdiyev AM, Abamor ES, Bagirova M, Rafailovich M. Antimicrobial effects of $\mathrm{TiO}_{2}$ and $\mathrm{Ag}_{2} \mathrm{O}$ nanoparticles against drug-resistant bacteria and leishmania parasites. Fut Microb. 2011;6:933-40.

306. Guzman M, Dille J, Godet S. Synthesis and antibacterial activity of silver nanoparticles against gram-positive and gram-negative bacteria. Nanomedicine. 2012;8:37-45.

307. Wan Y, Zhang D, Wang Y, Qi P, Wu J, Hou B. Vancomycin-functionalised Ag@TiO phototoxicity for bacteria. J Hazard Mater. 2011;186:306-12.

308. Devi LS, Joshi SR. Antimicrobial and synergistic effects of silver nanoparticles synthesized using: soil fungi of high altitudes of Eastern Himalaya. Mycobiol. 2012;40:27-34.

309. Juan L, Zhimin Z, Anchun M, Lei L, Jingchao Z. Deposition of silver nanoparticles on titanium surface for antibacterial effect. Int J Nanomed. 2010;5:261-7.

310. You J, Zhang Y, Hu Z. Bacteria and bacteriophage inactivation by silver and zinc oxide nanoparticles. Colloids Surf B Biointerfaces. 2011;85:161-7.

311. Gulcin I. Antioxidant activity of food constituents: an overview. Arch Toxicol. 2012;86:345-91.

312. Gulcin I, Topal F, Çakmakçı R, Bilsel M, Gören AC, Erdogan U. Pomological features, nutritional quality, polyphenol content analysis, and antioxidant properties of domesticated and 3 wild ecotype forms of raspberries (Rubus idaeus L.). J Food Sci. 2011;76:C585-93.

313. Rice-Evan CA, Miller N. Antioxidant property of phenolic compounds. Trends Plant Sci. 1997;2:152-9.

\section{Submit your next manuscript to BioMed Central and we will help you at every step:}

- We accept pre-submission inquiries

- Our selector tool helps you to find the most relevant journal

- We provide round the clock customer support

- Convenient online submission

- Thorough peer review

- Inclusion in PubMed and all major indexing services

- Maximum visibility for your research

Submit your manuscript at www.biomedcentral.com/submit
(O) BioMed Central 